\title{
SURFACE-GEOPHYSICAL TECHNIQUES USED TO DETECT EXISTING AND INFILLED SCOUR HOLES \\ NEAR BRIDGE PIERS
}

By Gary Placzek and F.P. Haeni

U.S. GEOLOGICAL SURVEY

Water-Resources Investigations Report 95-4009

Prepared in cooperation with the

\section{FEDERAL HIGHWAY ADMINISTRATION}

\author{
Hartford, Connecticut \\ 1995
}

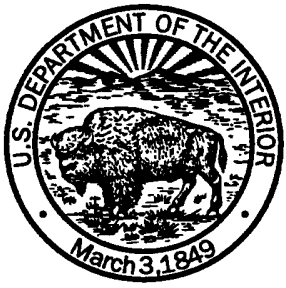




\section{U.S. DEPARTMENT OF THE INTERIOR \\ BRUCE BABBITT, Secretary}

\section{U.S. GEOLOGICAL SURVEY}

Gordon P. Eaton, Director

For additional information write to:

Chief, Branch of Geophysical Applications and Support, Office of Ground Water U.S. Geological Survey 450 Main Street Room 525 Hartford, CT 06103
Copies of this report can be purchased from:

U.S. Geological Survey

Earth Science Information Center Open-File Reports Section Box 25286, MS 517

Denver Federal Center

Denver, CO 80225 


\section{CONTENTS}

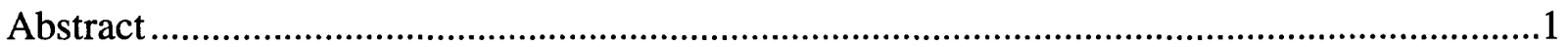

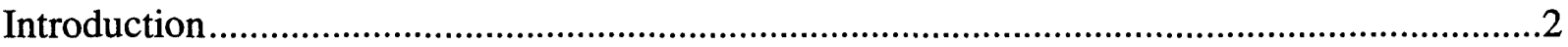

Purpose and scope

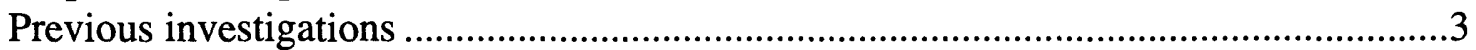

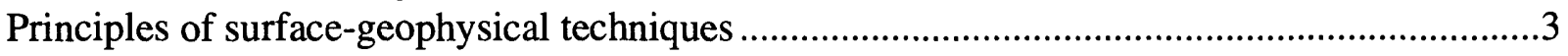

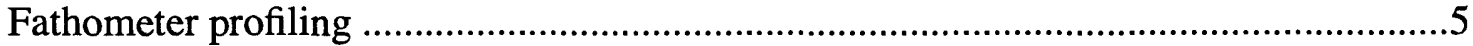

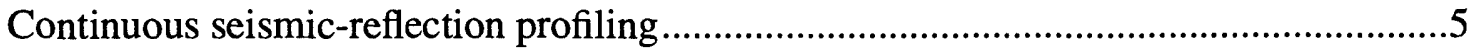

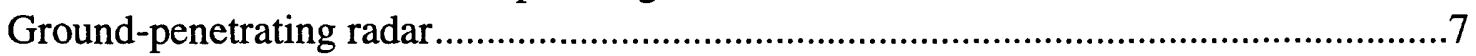

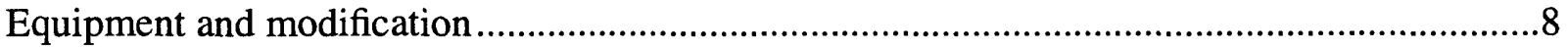

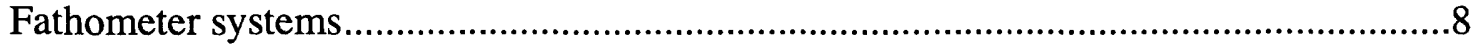

Continuous seismic-reflection profiling systems ………............................................10

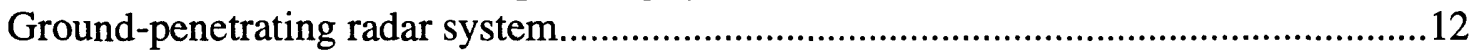

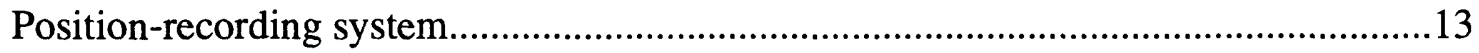

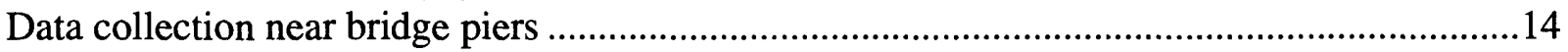

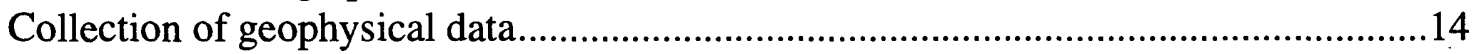

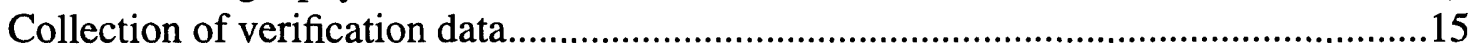

Processing techniques applied to surface-geophysical and position data....................................16

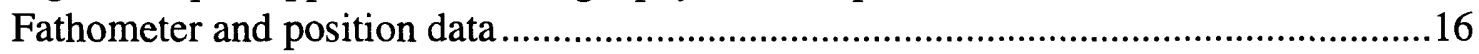

Color Fathometer and continuous seismic-reflection profiling data ..............................19

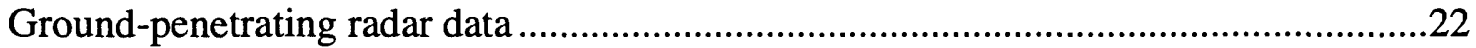

Results of surface-geophysical techniques at selected bridge sites .......................................... 24

Old Baldwin Bridge, Old Saybrook ...........................................................................24

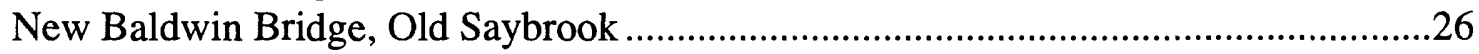

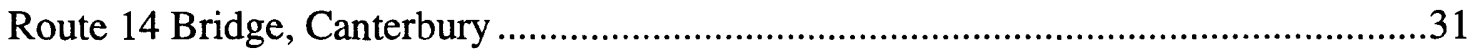

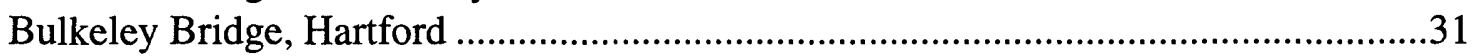

Route 4 Bridge, Farmington ....................................................................................36

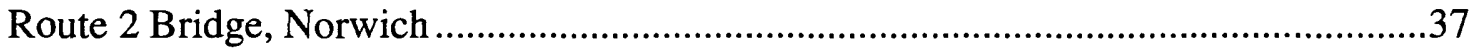

Future equipment modifications and research needs ..............................................................38

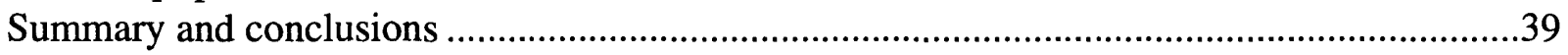

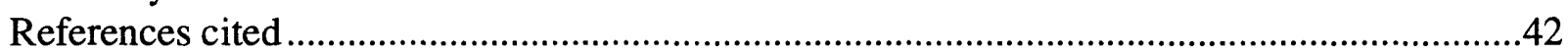

\section{FIGURES}

1. Map showing the bridge sites in Connecticut used for this study ..........................................

2. Positioned 200-kilohertz Fathometer cross-section 5 feet upstream of the piers at the Bulkeley Bridge, Hartford, Conn................................................................. 17

3. Three-dimensional bathymetric contour plot upstream from the Bulkeley Bridge,

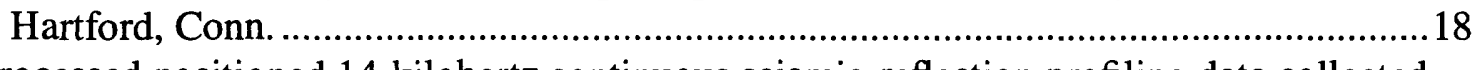

4. Unprocessed positioned 14-kilohertz continuous seismic-reflection profiling data collected

10 feet upstream from pier 4 of the Bulkeley Bridge, Hartford, Conn............................21

5. Digitally filtered, horizontally corrected, deconvolved 14-kilohertz data from figure 4 ........21

6. Gray-scale amplitude plot of 2- to 16-kilohertz swept-frequency record collected 10 feet upstream from pier 7 at the new Baldwin Bridge, Old Saybrook, Conn. (after construction). 


\section{FIGURES--continued}

7. Unprocessed 300-megahertz ground-penetrating radar data collected 2 feet upstream from the pier at the Route 14 bridge in Canterbury, Conn.............................23

8. Wiggle-trace plot of digitally filtered and migrated 300-megahertz ground-penetrating radar data from figure 7 ............................................................................................23

9. Unpositioned 200-kilohertz Fathometer profile collected 10 feet upstream from the piers at the old Baldwin Bridge, Old Saybrook, Conn. .25

10. Unpositioned 3.5-kilohertz continuous seismic-reflection profiling data collected 10 feet upstream from pier 8 at the old Baldwin Bridge, Old Saybrook, Conn. ........................25

11. The old and new Baldwin Bridge pier locations, Old Saybrook, Conn. .27

12. Unpositioned 200-kilohertz Fathometer profile collected along the proposed bridge alignment of the new Baldwin Bridge, Old Saybrook, Conn. (before construction) .....28

13. Unpositioned 200-kilohertz Fathometer data collected 15 feet upstream of the new

Baldwin Bridge, Old Saybrook, Conn. (during construction)...

14. Unpositioned 200-kilohertz Fathometer data collected 15 feet upstream of the new

Baldwin Bridge, Old Saybrook, Conn. (after construction)

15. Unpositioned 3.5-kilohertz continuous seismic-reflection profiling data collected 15 feet

upstream from the new Baldwin Bridge, Old Saybrook, Conn. (after construction) .....29

16. Unpositioned 14-kilohertz continuous seismic-reflection profiling data collected 15 feet upstream from the new Baldwin Bridge, Old Saybrook, Conn. (after construction) .....30

17. Black-and-white photograph of a 20-kilohertz color Fathometer cross section collected

12 feet upstream from pier 4 of the Bulkeley Bridge, Hartford, Conn............................33

18. Gray-scale amplitude plot of 1.5- to 10-kilohertz swept-frequency record collected

5 feet upstream from piers 4 and 5 at the Bulkeley Bridge, Hartford, Conn. .34

19. Unpositioned 7-kilohertz continuous seismic-reflection profiling data collected 20 feet upstream from the Bulkeley Bridge, Hartford, Conn. ..................................................34

20. Positioned 100-megahertz ground-penetrating radar data collected 15 feet upstream from piers 4 and 5 of the Bulkeley Bridge, Hartford, Conn. ..........................................35

21. Unpositioned 300-megahertz ground-penetrating radar data collected 4 feet east of the center pier at the Route 4 Bridge, Farmington, Conn..........................................36

22. Unpositioned 200-kilohertz Fathometer data collected 3 feet upstream from the piers at the Route 2 Bridge, Norwich, Conn.

\section{TABLES}

1. Typical reflection coefficients ........................................................................................6

2. Approximate values for electromagnetic properties of selected materials ...............................8

3. Summary of performance criteria for selected surface-geophysical techniques ......................39

4. Summary of geophysical data collected at six bridge sites in Connecticut .............................40 


\section{CONVERSION FACTORS AND ABBREVIATIONS}

Multiply

inch (in.)

foot (ft)

mile (mi)

cubic foot per second $\left(\mathrm{ft}^{3} / \mathrm{s}\right)$
By

25.4

0.3048

1.609

0.02832
To obtain

millimeter (mm)

meter (m)

kilometer $(\mathrm{km})$

cubic meter per second $\left(\mathrm{m}^{3} / \mathrm{s}\right)$

Other abbreviations used:

$\mathrm{dB}$, decibel

$\mathrm{kB} / \mathrm{s}$, kilobyte per second

$\mathrm{kHz}$, kilohertz

$\mathrm{kW}$, kilowatt

$\mathrm{MB}$, megabyte

$\mathrm{MHz}$, megahertz

$\mathrm{ms}$, millisecond

ns, nanosecond

$\mu \mathrm{S} / \mathrm{cm}$, microsiemens per centimeter

W, watt 


\title{
SURFACE-GEOPHYSICAL TECHNIQUES USED TO DETECT EXISTING AND INFILLED SCOUR HOLES NEAR BRIDGE PIERS
}

\author{
By Gary Placzek and F.P. Haeni
}

\begin{abstract}
Surface-geophysical techniques were used with a position-recording system to study riverbed scour near bridge piers. From May 1989 to May 1993, Fathometers, fixed- and swept-frequency continuous seismic-reflection profiling (CSP) systems, and a groundpenetrating radar (GPR) system were used with a laser-positioning system to measure the depth and extent of existing and infilled scour holes near bridge piers. Equipment was purchased commercially and modified when necessary to interface the components and (or) to improve their performance.

Three $200-\mathrm{kHz}$ black-and-white chartrecording Fathometers produced profiles of the riverbed that included existing scour holes and exposed pier footings. The Fathometers were used in conjunction with other geophysical techniques to help interpret the geophysical data. A $20-\mathrm{kHz}$ color Fathometer delineated scour-hole geometry and, in some cases, the thickness of fill material in the hole. The signal provided subbottom information as deep as 10 $\mathrm{ft}$ in fine-grained materials and resolved layers of fill material as thin as $1 \mathrm{ft}$ thick.
\end{abstract}

Fixed-frequency and swept-frequency CSP systems were evaluated. The fixedfrequency system used a 3.5-, 7.0-, or $14-\mathrm{kHz}$ signal. The $3.5-\mathrm{kHz}$ signal penetrated up to 50 $\mathrm{ft}$ of fine-grained material and resolved layers as thin as $2.5-\mathrm{ft}$ thick. The $14-\mathrm{kHz}$ signal penetrated up to $20 \mathrm{ft}$ of fine-grained material and resolved layers as thin as 1 -ft thick. The swept-frequency systems used a signal that swept from 2- to $16-\mathrm{kHz}$. With this system, up to $50 \mathrm{ft}$ of penetration was achieved, and fill material as thin as $1 \mathrm{ft}$ was resolved. Scourhole geometry, exposed pier footings, and fill thickness in scour holes were detected with both CSP systems.

The GPR system used an $80-, 100-$, or 300 -megahertz signal. The technique produced records in water up to $15 \mathrm{ft}$ deep that had a specific conductance less than $200 \mu \mathrm{S} / \mathrm{cm}$. The $100-\mathrm{MHz}$ signal penetrated up to $40 \mathrm{ft}$ of resistive granular material and resolved layers as thin as 2 -ft thick. Scour-hole geometry, the thickness of fill material in scour holes, and riverbed deposition were detected using this technique.

Processing techniques were applied after data collection to assist with the interpretation of the data. Data were transferred from the color Fathometer, CSP, and GPR systems to a personal computer, and a commercially available software package designed to process GPR data was used to process the GPR and CSP data. Digital filtering, predictivedeconvolution, and migration algorithms were applied to some of the data. The processed data were displayed and printed as color amplitude or wiggle-trace plots. These processing methods eased and improved the interpretation of some of the data, but some interference from side echoes from bridge piers and multiple reflections remained in the data. 
The surface-geophysical techniques were applied at six bridge sites in Connecticut. Each site had different water depths, specific conductance, and riverbed materials. Existing and infilled scour holes, exposed pier footings, and riverbed deposition were detected by the surveys. The interpretations of the geophysical data were confirmed by comparing the data with lithologic and (or) probing data.

\section{INTRODUCTION}

Riverbed scour near bridge piers is a widespread problem throughout the United States. Scour near bridge piers has caused scour holes to develop, piers to fail, and ultimately, bridges to collapse. Many bridge failures throughout the United States have been attributed to this problem. From 1961 to 1976, 46 of 86 major bridge failures were a result of scour near piers (Murillo, 1987). More bridge failures during that period were caused by scour than by earthquakes, wind, structural, corrosive, accidental, and construction-related causes. Streambed aggradation and degradation, contraction scour, and local scour were found to be the main contributing factors to scour near bridge piers (Richardson and others, 1991).

Measurements of riverbed scour and deposition near bridge piers are essential to studying the scour process. By understanding the scour process, better initial construction techniques and scour countermeasures can be developed to minimize scour effects. Maximum scour depths near a bridge pier usually occur during the peak of a flood when measurements are difficult, dangerous, or even impossible to collect. In addition, bed load on alluvial channels is redeposited shortly after the peak flow but long before the flood has receded (Trent and Landers, 1991), so scour holes can be infilled. If the scour hole has been infilled, data collected after the flood's peak using a sounding weight or a high-frequency
Fathometer will not measure the maximum scour depth. After the flood recedes, surfacegeophysical techniques may be able to detect and measure the maximum scour depth that occurred during the peak of the flood. Surfacegeophysical records collected near bridge piers contain a continuous profile of the water bottom and, at some sites, can delineate reflectors in the subbottom. These subbottom reflectors can be correlated to old scour surfaces, pier foundations, old channel beds, or geologic layers.

\section{In 1989, the U.S. Geological Survey} (USGS) and the Federal Highway Administration (FHWA) began a cooperative study to evaluate and improve the effectiveness of several surface-geophysical techniques used to detect riverbed scour near bridge piers. The study included evaluating surface-geophysical equipment, developing data-collection and interpretation methods, and applying these results to bridge sites in different physical settings. Six bridge sites in Connecticut were chosen for this study (fig. 1), and geophysical techniques were used to examine existing and infilled scour holes near piers at these sites. The sites differ in river width and depth, specific conductance of water (freshwater or saltwater), and in the types of river bottom and subbottom materials. Two of the larger sites, where geologic information was available, were designated as primary test sites. New or modified instrumentation and new data collection and interpretation methods were tested at the primary test sites.

\section{Purpose and Scope}

The purpose of this report is to describe (1) the surface-geophysical techniques used to measure existing and infilled scour holes near bridge piers; (2) the new or modified equipment, data-collection methods, and interpretation methods developed for this application; and (3) the interpretation of data collected 
from selected bridge sites in different physical settings. This report includes descriptions of the basic principles of the surface-geophysical techniques and equipment used during the study. Additional details are provided on datacollection methods and data processing and interpretation. Each of the six bridge sites are described with interpretations of the geophysical records. Finally, advantages and limitations of each geophysical technique and future development needs in this field are discussed.

\section{Previous Investigations}

Scour processes have been extensively studied, and mathematical models have been developed from physical models and field data. Numerous scour-prediction equations have been published (Anderson, 1974; Hopkins and others, 1980; Richardson and Richardson, 1989), but predicted scour depths can vary substantially when equations are applied outside the range of conditions for which they were developed (Jarrett and Boyle, 1986). Field measurements of scour depths are needed to put practical constraints and limits on these prediction equations (Trent and Friedland, 1992). Some of these field measurements can be made using geophysical techniques.

Surface-geophysical techniques have been used successfully to map the subbottom stratigraphy in lakes and rivers (Wright and others, 1984; Morrissey and others, 1985; Haeni, 1986; Hansen, 1986; Haeni and others, 1987; Reynolds and Williams, 1988, Cardinell and others, 1990; Beres and Haeni, 1991). Continuous seismic-reflection profiling (CSP) and ground-penetrating radar (GPR) techniques have been used to evaluate scour holes near bridge piers (Gorin and Haeni, 1989; Crumrine, 1991; Haeni and Placzek, 1991; Haeni and others, 1992; Placzek and others, 1993; Mueller and others, 1994). One study has shown that continuous seismic-reflection profiles could be used to determine quantitative material classification data (Hart and
Caulfield, 1989). The geophysical data collected for these studies were useful in determining depth of existing scour holes, thickness of fill material in infilled scour holes, depth to and extent of buried rip-rap, location of old river channels, depth to bedrock, and geometry of pier foundations.

\section{PRINCIPLES OF SURFACE- GEOPHYSICAL TECHNIQUES}

All the surface-geophysical techniques used in this study operate using the same basic principles of wave propagation and reflection. From the water surface, a signal is transmitted into water and is reflected back to the water surface by interfaces between materials with different physical properties. By observing the reflected signals, information about the depth to and the type of interface can be determined. The main differences between the individual geophysical techniques are the types of signals transmitted and the physical property changes that cause reflections. Fathometer and CSP systems use seismic signals, and reflections are caused by interfaces between materials with different acoustic properties. The GPR system uses electromagnetic signals, and reflections are caused by interfaces between materials with different electrical properties.

Seismic and electromagnetic signals behave differently as they travel through the same material. They travel at different velocities, and different characteristics of the materials can attenuate, scatter, or reflect the energy. Seismic signals can be scattered by gas or air bubbles, therefore, CSP techniques are not used in settings with gassing organic materials. Electromagnetic signals are sensitive to electrical conductivity and are attenuated quickly in saltwater or conductive geologic materials such as silts and clays; therefore, GPR techniques are not used in saltwater or to penetrate silt and clay formations. 


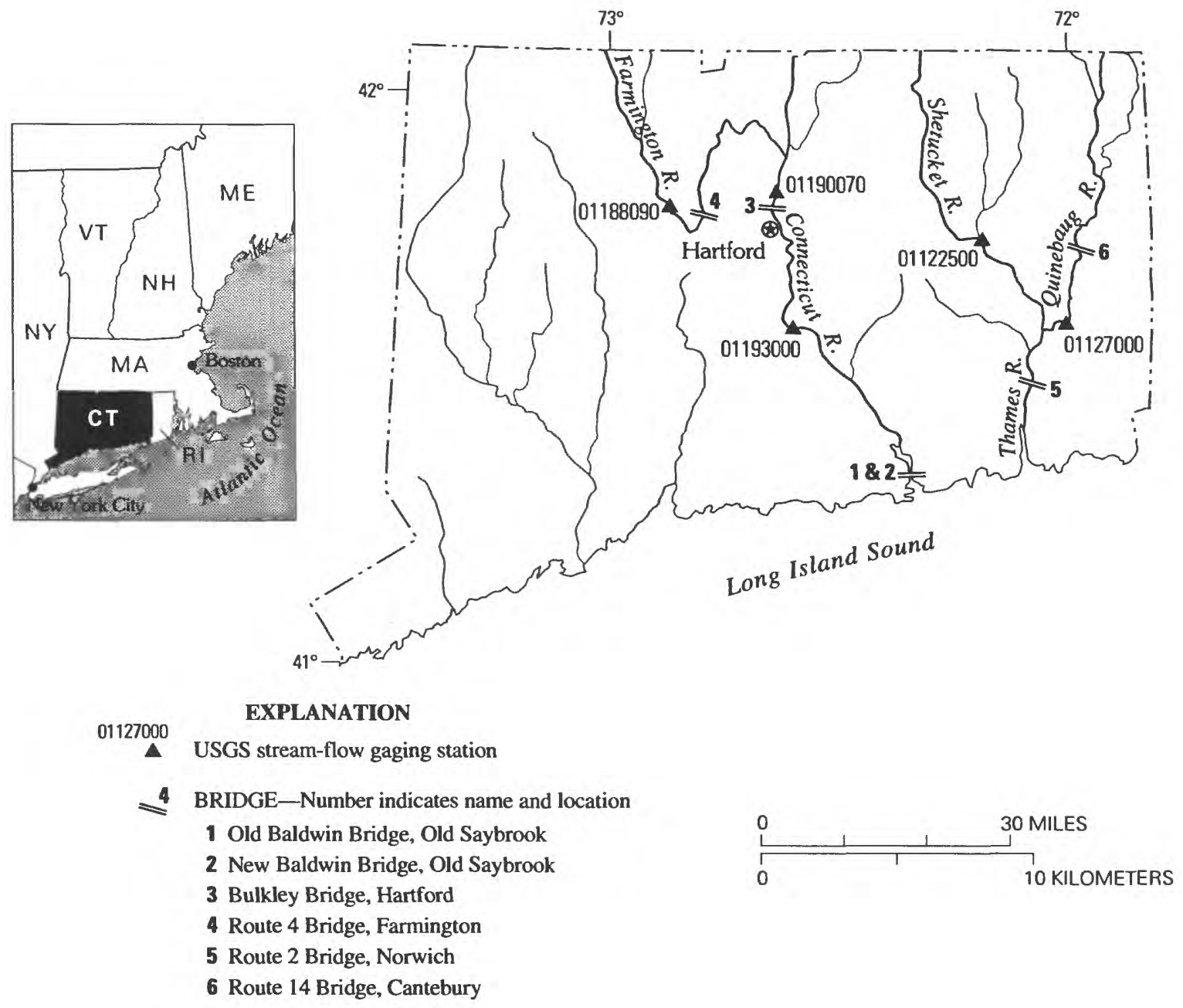

Figure 1. Bridge sites in Connecticut used for this study. 


\section{Fathometer Profiling}

Fathometers determine water depth by repeatedly transmitting seismic energy through the water column and recording the arrival time of the reflected energy from the water bottom. The time required for the seismic signal to travel from its source to a reflector and back is known as the two-way travel time, and it is measured in milliseconds (ms) (equal to $1 \times 10^{-3}$ seconds). The Fathometer calculates the depth to a water bottom by dividing the two-way travel time by two and multiplying the result by the velocity of sound through water:

$$
D=V \frac{t}{2}
$$

where: $D=$ depth to the water bottom (ft),

$V=$ velocity of sound through water (ft/s), and

$t=$ two-way travel time (s).

The depth value is printed as a continuous graphic profile and (or) displayed as a numeric value by the Fathometer. Fathometers are calibrated by adjusting the value of $\mathrm{V}$ (eq. 1 ), which may vary slightly depending on water type. Most Fathometers use a narrowbandwidth $200-\mathrm{kHz}$ seismic signal. These Fathometers provide accurate depth data, but little or no information about the subbottom. Fathometers that use a lower frequency signal, such as $20 \mathrm{kHz}$, can detect reflected energy from subbottom interfaces, such as the bottom of an infilled scour hole. A color Fathometer is calibrated to measure and display in color the amplitude of the reflected signal, which, in constant water depths, can be related to characteristics of the bottom material.

\section{Continuous Seismic-Reflection Profiling}

Continuous seismic-reflection profiling (CSP) systems transmit seismic energy from a transducer located just beneath the water surface. The energy passes through the water column and into the subbottom. Where a change in acoustic impedance occurs, such as at the water/bottom interface, part of the seismic energy is reflected back to the water surface. The remainder of the seismic energy is transmitted further into the material. The amount of energy that is reflected by an interface is determined by the reflection coefficient of that interface, which is dependent upon the acoustic impedance of the material above and below the interface.

Acoustic impedance is defined as the product of the density of a material and the velocity of sound through the material:

$$
Z=\rho V
$$

where: $Z$ = acoustic impedance $\left(\mathrm{g} / \mathrm{m}^{2} \mathrm{~s}\right)$,

$\rho=$ density of the material $\left(\mathrm{g} / \mathrm{m}^{3}\right)$, and

$V=$ velocity of sound through the material $(\mathrm{m} / \mathrm{s})$.

The reflection coefficient is defined as the difference of the acoustic impedances of the materials at an interface divided by their sum:

$$
R=\frac{Z_{2}-Z_{1}}{Z_{2}+Z_{1}}=\frac{A_{r}}{A_{i}}
$$

where: $R=$ reflection coefficient for this interface,

$Z_{1}, Z_{2}=$ acoustic impedance of material above and below the interface, and

$$
\begin{gathered}
A_{r} A_{i}=\begin{array}{l}
\text { amplitude of the reflected and } \\
\text { incident waves at the } \\
\text { interface. }
\end{array} \\
\text {. }
\end{gathered}
$$

Typical reflection coefficients for selected geologic interfaces are shown in table 1 . These reflection coefficients indicate that the amplitude of the reflected signal from a water/sand interface $(R=0.3)$ is larger than the amplitude of the reflected signal from a water/mud interface $(\mathrm{R}=0.05)$, in similar water depths ( $\mathrm{A}_{i}$ is constant). In systems that have color amplitude printouts or displays, each 
color represents a range of amplitudes of the reflected signal $\left(A_{r}\right)$. When the water depth is constant, the amplitude of the incident wave $\left(\mathrm{A}_{i}\right)$ at the water/bottom interface is constant, and the color displayed representing that interface can be related to its reflection coefficient. A number of studies have shown that reflection coefficients are related linearly to bulk density, porosity, and median grain size of marine sediments (Faas, 1969; Hamilton, 1970; Parrott and others, 1980).

The depth scale of a CSP record is calculated using equation 1 where $D$ is the depth to any reflector and $V$ is the velocity of sound through the material above it. Typically, the velocity of sound through water (about 4,888 $\mathrm{ft} / \mathrm{s}$; Sheriff, 1984) and saturated sediments (about 5,075 ft/s; Haeni, 1988) is assumed to be $5,000 \mathrm{ft} / \mathrm{s}$, and the same vertical scale for the water column is used to measure depths in the subbottom. When more precision is needed, a separate depth scale for the water column and for saturated sediments is calculated using appropriate velocities.
The frequency of the seismic signal used by the CSP technique determines the maximum penetration depth and resolution. A high-frequency signal has a short wavelength and is attenuated by subbottom materials but provides high resolution of subbottom interfaces (Sylwester, 1983). A low-frequency signal has a longer wavelength and is attenuated less by subbottom materials but provides poorer resolution. The fixed-frequency CSP technique uses a narrow-bandwidth fixed-frequency signal usually centered at $3.5,7.0$, or $14 \mathrm{kHz}$. The CSP technique using a $14-\mathrm{kHz}$ signal can be used in water as shallow as $4 \mathrm{ft}$, can penetrate up to $20 \mathrm{ft}$ into the subbottom in certain materials, and can detect fill material as thin as $1 \mathrm{ft}$ in a scour hole. The CSP technique using a $3.5-\mathrm{kHz}$ signal can be used in water as shallow as $7 \mathrm{ft}$, can penetrate up to $100 \mathrm{ft}$ into the subbottom in certain materials, and can detect fill material as thin as $2.5 \mathrm{ft}$ in a scour hole. Swept-frequency (chirp) CSP techniques that sweep from 2 to $16 \mathrm{kHz}$ can be used in

\section{Table 1. Typical reflection coefficients}

[Modified from Sylwester, 1983]

\begin{tabular}{cc}
\hline Interface & Reflection coefficient \\
\hline Water/air & -1.0 \\
Water/limestone & 0.5 \\
Water/sand & $.3-.4$ \\
Water/clay or silt & $.1-.2$ \\
Water/mud & $.05-.1$ \\
Mud/clay or silt & .1 \\
Clay/sand & .1 \\
Sand/limestone & .2 \\
Clay/limestone & .3 \\
Sand/granite & .4 \\
\hline
\end{tabular}


water as shallow as $1 \mathrm{ft}$, can penetrate $200 \mathrm{ft}$ into the subbottom in silts and clays, and can detect fill material as thin as 3 in. in a scour hole (Schock and LeBlanc, 1990).

The frequency of the seismic signal used also determines the size and weight of the transducer required to generate the signal. Generally, transducers that generate low-frequency signals are larger, heavier, and have wider beam angles than transducers that generate high-frequency signals. The beam angle of a transducer or antenna is the area beneath the device that contains most of the energy of the signal. A wide beam angle allows energy to be reflected by objects alongside of as well as under the transducer. These objects include the shoreline and the sides of piers. Echoes from the shoreline or from piers (side echoes) can interfere with the data.

Another source of interference in geophysical data is caused by multiple reflections. When a signal travels from the transducer to the water bottom, it is reflected by the bottom. When the signal returns to the surface it can be reflected at the air/water interface and transmitted back to the bottom. It is reflected by the bottom again and is received at the transducer a second time. This is called a second arrival or a water-bottom multiple. The energy may continue to ring in the water column causing more than one multiple reflection. Water-bottom multiples are most evident when the water-bottom reflection coefficient is large, as in rivers with hard bottoms.

\section{Ground-Penetrating Radar}

The principles used by the GPR technique are similar to those used by Fathometer and CSP techniques. GPR systems, which can be used on land or in water, radiate short pulses of electromagnetic energy from a broad-bandwidth transmitting antenna. When used on water, the energy is transmitted from the antenna floating on the water surface. This energy passes through the water column and into the subbottom. Where a change in the electrical properties occurs, such as at the water/bottom interface, part of the energy is reflected back to the water surface. The remainder of the energy is transmitted further into the material. The reflected signal received by an antenna is transformed to the audio-frequency range, amplified, recorded, processed, and displayed. The ability of the electromagnetic energy to penetrate a material depends upon the specific conductance of the material.

The GPR record consists of a continuous graphic display of reflected energy over a set time interval. The set time interval is the two-way travel time, measured in nanoseconds (equal to $1 \times 10^{-9}$ seconds). The depth of water and the thickness of geologic material in the subsurface can be determined if the velocity of the electromagnetic energy $\left(V_{m}\right)$ through the material is known. $V_{m}$ through a particular material is calculated as follows:

$$
V_{m}=\frac{c}{\sqrt{E_{r}}}
$$

where: $V_{m}=$ velocity of electromagnetic energy $(\mathrm{ft} / \mathrm{s})$,

$c=$ speed of light in free space $(\mathrm{ft} / \mathrm{s})$ (approximately $3 \times 10^{8}$ ), and

$E_{r}=$ relative dielectric permittivity (dimensionless ratio).

$E_{r}$ is a measure of the capacity of a material to store a charge when an electric field is applied relative to the same capacity in a vacuum (Sheriff, 1984). Approximate values of $E_{r}$ and $V_{m}$ of selected materials are given in table 2 . The depth to a reflector can be calculated using equation 1 . Note that $V_{m}$ through water differs from $V_{m}$ through saturated sediments, so the vertical depth scale calculated for the water column cannot also be used for the subbottom. Separate depth scales are generated for materials with different $V_{m}$ values. 
The penetration depths achieved using GPR techniques depend on the frequency of the signal used and on the specific conductance of water and bottom materials. In general, the GPR system will penetrate resistive materials and will not penetrate conductive materials. Dense, moist clays impede performance of GPR, and saltwater makes the technique ineffective. GPR techniques work best in shallow (less than $20 \mathrm{ft}$ ) freshwater with granular bottom and subbottom sediments. Electromagnetic energy seldom penetrates more that $100 \mathrm{ft}$ into the subbottom (Wright and others, 1984) and, in highly conductive material, may only penetrate a few feet (Olhoeft, 1984). Using the $80-\mathrm{MHz}$ antennas, penetration depths of at least $20 \mathrm{ft}$ into the subbottom have been achieved through water less than $20 \mathrm{ft}$ deep with a specific conductance of $155 \mu \mathrm{S} / \mathrm{cm}$ (Gorin and Haeni, 1989). The frequency used determines the resolution of the technique, which can range from $1 \mathrm{ft}$ with a $300-\mathrm{MHz}$ antenna to $2.5 \mathrm{ft}$ with an $80-\mathrm{MHz}$ antenna. Multiple reflections are less common in GPR data than in CSP data, but side echoes from piers can cause interference in the GPR data.

\section{EQUIPMENT AND MODIFICATION}

The geophysical instruments used in this study were commercially available, and some modifications were required to assemble the systems. Fathometer, CSP, and GPR systems were used as purchased, but improvements were made to each system to better suit them for scour surveys.

\section{Fathometer Systems}

Three black-and-white chart-recording Fathometers were used during this study. One of the Fathometers used was the Lowrance ${ }^{1}$ model X-15B, a 192-kHz black-and-white chart-recording Fathometer. The system required a 12-volt dc power supply and consisted of a lightweight $(5 \mathrm{lb})$ control unit with a built-in belt-driven chart recorder and a 3-lb transducer. Bathymetric data were recorded graphically on the chart, and pier locations and comments were written directly

\footnotetext{
${ }^{1}$ The use of trade names is for identification purposes only and does not constitute endorsement by the U.S. Geological Survey.
}

Table 2. Approximate values for electromagnetic properties of selected materials

[Modified from Geophysical Survey Systems, Inc., 1987; $\mu \mathrm{S} / \mathrm{cm}$, microsiemens per centimeter at 25 degrees Celsius; $\mathrm{ft} / \mathrm{ns}$, feet per nanosecond]

\begin{tabular}{lccc}
\hline Material & $\begin{array}{c}\text { Specific conductance } \\
(\mu \mathrm{S} / \mathbf{c m})\end{array}$ & $\begin{array}{c}\text { Relative dielectric } \\
\text { permittivity }\left(\mathbf{E}_{\boldsymbol{r}}\right) \\
(\mathbf{d i m e n s i o n l e s s ~ r a t i o )})\end{array}$ & $\begin{array}{c}\text { Velocity of } \\
\text { electromagnetic } \\
\text { energy, } \mathbf{V}_{\boldsymbol{m}}(\mathbf{f t} / \mathbf{n s})\end{array}$ \\
\hline Air & 0 & 1 & 1 \\
Dry sand & $0.001-10$ & $4-6$ & $0.416-0.498$ \\
Fresh water & $1-300$ & 81 & .111 \\
Saltwater & 40,000 & 81 & .111 \\
Saturated sand & $1-100$ & 30 & .180 \\
Saturated silt & $10-100$ & 10 & .321 \\
Saturated clay & $1,000-10,000$ & $8-12$ & $.0301-.375$ \\
\hline
\end{tabular}


on the chart record during data collection. The amplitude of the reflected signal was displayed using a gray scale. A hard bottom appeared as a wide, dark gray line indicating a strong reflection, and a soft muddy bottom appeared as a narrow, light gray line indicating a weak reflection. The depth data were accurate to within 0.6 percent of the full-scale depth. For example, with a 50-ft full-scale depth, the depth to the water bottom was determined to within 4 in. Side echoes rarely occurred due to the narrow $\left(8^{\circ}\right)$ beam angle of the transducer. The tops of exposed pier footings were detected when the transducer passed over the footings. The 192-kHz Fathometer signal did not penetrate most bottom sediments because of its high frequency and, consequently, did not detect fill in the scour holes. This Fathometer was not configured to output digital depth data so it could not be interfaced with a laser-positioning system.

The Raytheon 2154D model DE-1190, a $200-\mathrm{kHz}$ black-and-white chart-recording Fathometer, produced records similar to those of the Lowrance X-15B. The Raytheon required a 12 -volt dc power supply and consisted of a 25 -lb control unit with a built-in belt-driven chart recorder and a 4-lb transducer. An Odom Digitrace module was added to the standard Raytheon unit so that digitized depth data could be transferred from the Fathometer to a positioning system via an RS-232 serial communication port.

The 45-16 Innerspace Technology model 448 black-and-white chart-recording Fathometer produced records similar to those from the Raytheon 2154D but used a solidstate thermal printer instead of a mechanical belt and stylus. An RS-232 serial interface was built into the $30-1 b$ unit so it could be interfaced with a laser-positioning system. The 5-lb transducer generated a $208-\mathrm{kHz}$ signal with a $3^{\circ}$ beam angle, and an optional $125-\mathrm{kHz}$ transducer is available for use with this Fathometer. This Fathometer was controlled by an internal microprocessor and was the most advanced Fathometer used in this survey.

All three black-and-white chart-recording Fathometers were portable and provided clear, accurate information on water depth, existing scour holes, the top of submerged debris, and the top of exposed pier footings. One of the Fathometers was used simultaneously with other geophysical systems to provide bathymetric records, which aided in the interpretation of CSP and GPR data.

A variable-frequency color Fathometer, the SeaTex model HE-730, manufactured by Si-Tex, Inc. was used to profile and detect fill in existing scour holes. The purchased system required a 12 -volt dc power supply and consisted of a 35-1b control unit and color monitor and a $15-\mathrm{lb}$ transducer. One of six possible frequencies $(20,40,60,75,88$, or 100 $\mathrm{kHz}$ ) was transmitted by a single transducer, with a frequency-dependent beam angle. A 20$\mathrm{kHz}$ signal with a beam angle of $44^{\circ}$ was used in this study to maximize penetration depths, but the wide beam angle caused side echoes to appear in the records. A minimum of $5 \mathrm{ft}$ of water was required to operate the system, and a maximum of $10 \mathrm{ft}$ of penetration into the subbottom was observed. Subbottom layers were resolved to within $1 \mathrm{ft}$ with this unit. A color video display of the data appeared during data collection, but a printed bathymetric profile was not produced during data collection.

The HE-730 system assigned different colors to different amplitudes of the reflected signals. A minimum threshold was set by the sensitivity control that controlled the smallest amplitude plotted on the screen. The smallest amplitude reflection was displayed as light blue. Signals with amplitudeS that were $6 \mathrm{~dB}$ higher, or about twice as large, were displayed as violet. Subsequent color changes occurred in 6-dB steps, and four additional colors were used: white, green, yellow, and red. Assuming a constant water depth, a bottom represented 
by red had a higher reflection coefficient and was harder than that represented by light blue.

A recording-interface box, made by $\mathrm{Si}$ Tex, was added to the system so the analog data was recorded by a standard audio tape recorder requiring a 110 -volt ac power source. The data were stored on two channels of a standard audio cassette. The left channel recorded a modulated trigger pulse, which indicated the time of the beginning of each individual sounding. The right channel stored a modulated data signal from each sounding. During data collection, the data were positioned by noting the tape count at landmarks such as piers.

The HE-730 system initially had several limitations that eventually were overcome. The color step size was fixed at $6 \mathrm{~dB}$, so smaller changes in the signal could not be displayed as a color change on the color monitor. An event mark button was not available on the system so position data relied solely on tape counts noted in the field. A hard copy of the data was not produced by the system, and the only way to review the data was to replay the data through the system from tape and observe the color monitor. A hard copy could be obtained by photographing the video monitor.

Modifications and improvements were made to the HE-730 color Fathometer system during this study. A hardware modification allowed the color step size to be changed from 6 to $4 \mathrm{~dB}$ in order to show smaller changes in the return signal and to improve the visual display. An event mark button was added that allowed vertical-line marks to be recorded in the data during data collection. The cassette tape recorder was replaced by a digital-audio tape (DAT) recorder. This improved the quality of the recorded signal by using a digital format rather than an analog format. A method to transfer color Fathometer data to a personal computer (PC) was developed that allowed digital processing of the color Fathometer data and printing capability.

\section{Continuous Seismic-Reflection Profiling Systems}

Two types of CSP systems were used for this study-a fixed-frequency system and a swept-frequency system. The fixed-frequency CSP system was tuned to a single frequency between 3.5 and $14.0 \mathrm{kHz}$ and was used to profile existing and infilled scour holes. The system from ORE International, Inc. consisted of a model $5430 \mathrm{~A}$ transmitter, a model $5210 \mathrm{~A}$ receiver, one of two transducer configurations, an EPC model 8700 thermal graphic recorder and annotator, and a DAT recorder. The signal frequency and signal power were set on the transmitter, gain and filter settings were set on the receiver, and a real-time graphic plot was generated by the thermal graphic recorder. The analog data were recorded in digital format by the DAT recorder onto standard DAT cartridges. The transmitter, annotator, receiver, and DAT recorder were rack-mounted in two cases to increase the portability of the system. The total weight of all the equipment, not including the transducers, was about 220 lbs. All units required a 110 -volt ac power supply and were powered by a portable $1,000-\mathrm{W}$ generator.

Two different types of transducer configurations were used with the fixed-frequency CSP system. A 150-lb rectangular array of four model 134 transducers transmitted a signal tuned between 3.5 and $7.0 \mathrm{kHz}$ in two modes of operation. When two transducers transmitted and the other two received energy (separate mode), the beam angle was wider and penetration depths were less than when all four transducers transmitted and then received the reflected energy (combined mode). Side echoes were detected in both modes of operation, and ringing within the transducer produced parallel lines across the top of the CSP record that interfered with data from shallow water. The presence of multiple reflections in the records increased in the combined mode as did the transducer ringing, which complicated 
data interpretation. In the combined mode, the $3.5-\mathrm{kHz}$ beam angle was $55^{\circ}$ and the $7.0-\mathrm{kHz}$ beam angle was $35^{\circ}$. In the separate mode, the $3.5-\mathrm{kHz}$ beam angle was $120^{\circ}$ by $55^{\circ}$ and the $7.0-\mathrm{kHz}$ beam angle was $80^{\circ}$ by $35^{\circ}$. The transducer array was usually operated at $7.0 \mathrm{kHz}$, and the separate mode was used in shallow water. A minimum water depth of $5 \mathrm{ft}$ was required to avoid the ringing interference. When the transducer was tuned to $3.5 \mathrm{kHz}$, interfaces $2.5 \mathrm{ft}$ thick could be resolved. In fine-grained material, up to $100 \mathrm{ft}$ of subbottom penetration was obtained, whereas in coarser materials, subbottom penetration was limited to 20 to $30 \mathrm{ft}$.

The second transducer configuration was a single element, 50-lb, model T14, cylindrical $14-\mathrm{kHz}$ transducer. Internal ringing was a problem with this transducer, which often produced poor records at scour sites especially in very shallow water. This transducer was able to resolve interfaces to within $1 \mathrm{ft}$.

CSP data saved on DAT cartridges were reviewed and processed two ways. In the first method, the tape was replayed through the receiver and the gains, filters, and verticaldepth scales were re-adjusted as the data were printed on the graphic recorder. Regions of interest on the record were enhanced if the acquisition parameters were not set optimally during data collection or if a new region of interest developed. The second technique involved transferring the data to a PC for processing. A discussion of this method is presented in the processing section of this report.

The two major shortcomings of the standard CSP system were the ringing in the $14-\mathrm{kHz}$ transducer and the ringing in the outgoing transmitter pulse. In a new $50-\mathrm{lb} 14-\mathrm{kHz}$ transducer (also model T-14), the transmitter and receiver elements were separated, which reduced some of the internal transducer ringing. Implementing an active ring-damping circuit into the transmitter sharpened the outgoing electronic pulse to the transducer and reduced ringing in the $3.5,7.0$, and new 14$\mathrm{kHz}$ records. The new $14-\mathrm{kHz}$ transducer, using the ring-damping circuit, was designed to work in water as shallow as $3 \mathrm{ft}$.

A modification to the EPC graphic recorder allowed the operator to print both the positive and negative components of the return signal or just the positive portion of the signal. This modification aided in the interpretation of some of the data.

Two swept-frequency CSP systems were used during this study - the Datasonics CAP-6000 and the Precision Signal X-Star system offered by EG\&G Marine Instruments. The two systems have differences, but their basic designs are similar. The systems consisted of a computer-based control unit and signal processor in one $120-\mathrm{lb}$ case and a color monitor in another 80 -lb case. The control unit recorded the data onto 8-mm Exabyte tape cartridges. An external printer and a transducer mounted in a tow fish were also part of the system. The Datasonics $1.5-$ to $10-\mathrm{kHz}$ tow fish weighed $360 \mathrm{lb}$, and the Precision Signal 2- to $16-\mathrm{kHz}$ tow fish weighed $280 \mathrm{lb}$. The fins of the Datasonics tow fish were cut for use near piers in scour projects, but its weight was not reduced substantially. A 1,000-W, 110-volt ac generator was used to power each system. Minimal setup parameters were needed to begin data collection, and the data-collection routine was controlled by a menu-driven program. The color monitor provided a real-time color amplitude display of bathymetric and subbottom information. A hardness or sediment classification plot of the river bottom also was displayed during data collection.

Both swept-frequency CSP systems produced high-resolution records of existing scour holes, fill in the holes, and geologic layers in the subbottom. Both swept-frequency systems were easier to operate but more difficult to troubleshoot than the ORE system because many controls were automatically set by the equipment. 
Since the conclusion of the study, new swept-frequency CSP systems have become commercially available. Precision Signal has introduced the Mini Star, which sweeps from 4 to $20 \mathrm{kHz}$ using a $55-\mathrm{lb}$ transducer and $20-\mathrm{lb}$ Sparc II workstation. DataSonics has introduced the Chirp II system, which uses the same transducer as the earlier DataSonics system but with a 80486 processor. ORE International has introduced the GeoChirp, which sweeps from 2 to $8 \mathrm{kHz}$ or 1.5 to $11.5 \mathrm{kHz}$ using the same transducer from its fixed-frequency CSP system and upgraded electronic controls.

\section{Ground-Penetrating Radar System}

A GPR system using 80-, 100-, or 300$\mathrm{MHz}$ antennas was used to profile existing scour holes and to detect infilled scour holes. The SIR-8 GPR system, manufactured by Geophysical Survey Systems, Inc. (GSSI), consisted of a control unit, a digital tape recorder, a graphic recorder, and an antenna.

The system was powered either by a 12 -volt dc or 110-volt ac power supply. The control unit controlled the gain, filter, maximum time (depth) recorded, and other setup parameters; the digital tape recorder recorded the data; the graphic recorder printed the profile during data collection; and the antenna determined the frequency of the signal used. The total weight of the instrumentation, not including the antennas, was about $100 \mathrm{lb}$. The antenna weights were $80 \mathrm{lb}$ for the single $80 \mathrm{MHz}, 25 \mathrm{lb}$ for the single $100 \mathrm{MHz}$, and $30 \mathrm{lb}$ for the single 300 $\mathrm{MHz}$ antenna. The antennas were used in a mono-static mode, requiring one antenna, and in a bi-static mode, requiring two antennas separated by a fixed distance. In the monostatic mode, one antenna transmitted and received a signal; in the bi-static mode, one antenna transmitted a signal and the other received it. The 80 and $100-\mathrm{MHz}$ antennas were used in both the mono-static and bi-static modes. The $300-\mathrm{MHz}$ antenna had separate transmitter and receiver antennas built into a single housing, so although it was contained a single housing, it operated in the bi-static mode. A removable electronic module located in the antenna housings determined the amount of power transmitted by the antennas. A lowpower $(20$ or $40 \mathrm{~W})$ transmitter was used in the $300 \mathrm{MHz}$ antenna and the mono-static 80 - and $100-\mathrm{MHz}$ antenna configurations. A highpower $(2.5$ or $5 \mathrm{~kW})$ transmitter was used in the bi-static 80 - and 100-MHz antenna configurations. The high-power, bi-static $80-\mathrm{MHz}$ antennas provided up to $20 \mathrm{ft}$ of penetration into the subbottom, in $10 \mathrm{ft}$ of freshwater, and resolved layers as thin as $2.5 \mathrm{ft}$. On land, the $80-\mathrm{MHz}$ antennas penetrated more than $50 \mathrm{ft}$ of resistive material. The low-power $300-\mathrm{MHz}$ antenna provided up to $10 \mathrm{ft}$ of penetration into the subbottom in $2 \mathrm{ft}$ of freshwater, and it resolved layers as thin as $1 \mathrm{ft}$.

Data recorded on 3M DC600HC tape cartridges were reviewed and processed two ways. In the first method, the tape was replayed through the control unit, and the gains and various print controls were readjusted as the data were printed on the graphic recorder. The vertical-depth scale was fixed during data collection. The second method involved transferring the data to a PC for processing, which allowed the verticaldepth scale to be shortened and processing algorithms to be applied. A discussion of this method is presented in the processing section of this report.

A major limitation of the standard radar antennas was that they were not designed to be used in water. The wheels were removed from the $80-$ and $300-\mathrm{MHz}$ antennas, and the cases were sealed so water did not leak into them. Because the removable electronic modules and the cable were connected on the top side of the standard antennas, care was used during data collection not to splash water near those parts. New fiberglass cases for the 100- 
$\mathrm{MHz}$ antennas were designed and built with water-resistant connectors mounted on top of the cases, and a 5-kW transmitter and a singlestage receiver were permanently mounted inside the waterproof cases. These could be used only in the bi-static mode of operation. The tops of both antennas were shielded to reduce interference from reflections from bridge decks. The use of a fiber-optic link between the antennas, rather than a standard coaxial connection, improved the quality of the GPR data. The modified 100-MHz antennas provided the same quality data as the standard antennas, but were better suited to collect data in scour investigations. The standard and modified $100-\mathrm{MHz}$ antennas were much lighter and easier to maneuver near bridge piers than the $80-\mathrm{MHz}$ antennas and provided comparable penetration depths and better resolution.

\section{Position-Recording System}

Position data were used to correlate the geophysical records with the pier locations, to correct the horizontal scale of the geophysical records and to review the tracklines of the boat's paths during data collection to ensure complete coverage of the survey area. The Hydro I, a laser-positioning system manufactured by IMC, was used with a Fathometer and a data logger or Hypack acquisition software to collect position data before 1993. After 1993, an upgraded version of the system, the Hydro II, manufactured by Laser Technology, Inc., was used with a Fathometer and acquisition software on a PC to collect position data.

The Hydro position-recording systems recorded the boat's position $(x, y)$ relative to a fixed point and the corresponding water depth (z). Although the Hydro II's laser is accurate to within $0.3 \mathrm{ft}$, the practical accuracy, which includes tracking errors, is closer to $2 \mathrm{ft}$. A shore station and a ship station were required by these systems. The shore station consisted of a laser distance-measuring device, a theodolite (an angle-measuring device), and a radio link that transmitted the coordinates of the boat's location to the boat. A person was required on shore to manually track the boat with the laser. The ship station consisted of a data logger/radio link (or a PC/radio link), which received the position $(x, y)$ data from the shore station and the depth data (z) from a Fathometer. The data logger (or PC) on the ship recorded the boat's position and the water depth at a programmed distance or time interval. Usually, the $x-y-z$ values were recorded every time the boat travelled a distance of $5 \mathrm{ft}$. A mark signal was transmitted to the geophysical equipment at $10-\mathrm{ft}$ distance intervals. During data collection, the data logger (or PC) also aided in navigation by indicating how far the boat was to the left or right of the programmed trackline. When using the data logger, the data were transferred from the data logger to a PC. The Hydro I hydrographic software was used to review the boat's tracklines and bathymetric profiles and to edit and print two-dimensional plots of the tracklines and profiles.

An additional data-collection and processing software package, Hypack, written by Coastal Oceanographics, was used on an IBMcompatible PC in the boat during data collection. At the Bulkeley Bridge, the geometry and locations of the bridge piers were programmed into Hypack from bridge-construction plans. At the Baldwin Bridge, the locations of the piers were programmed into Hypack on site by positioning the boat at the front and back of each pier and recording the position. Hypack provided a real-time graphic display of the bathymetry and the boat's position in relation to the piers, desired trackline, and previous boat paths. By monitoring these data during data collection, complete coverage of the scour site, as well as the quality of the position and depth data, were assured. On the boat, Hypack replaced the data logger and recorded the data directly to a file on the PC in ASCII format. The PC used two serial ports. One port read 
depth data from a Fathometer and the other read position data from the radio-link unit. After data collection, Hypack or the Hydro I software was used to edit and print data. Additional programs, Isomate and Surfer, were used to create two-dimensional and three-dimensional contour plots from the data. Further details are included in the processing section of this report.

\section{DATA COLLECTION NEAR BRIDGE PIERS}

Successfully collecting surface-geophysical data near bridge piers begins with the choice of an appropriate technique. The appropriate choice of the geophysical technique(s) to use for detecting and measuring existing and infilled scour surfaces depends on two factors. First, the chosen technique must be able to provide the penetration and resolution required. For example, if the purpose of the survey is to detect infilled scour holes, a 200$\mathrm{kHz}$ Fathometer will not provide the subbottom information required. If the purpose is to map the bathymetry of existing scour holes, the $200-\mathrm{kHz}$ Fathometer probably will provide adequate results. Second, the chosen technique must work in the setting at the scour site. For example, CSP techniques will not work in water depths less than $3 \mathrm{ft}$, and GPR techniques will not work well in water with a specific conductance greater than $1,000 \mu \mathrm{S} / \mathrm{cm}$.

Once a technique is chosen, the logistics at the site need to be considered. The equipment may be operated from a small or large boat or from the shore or a bridge deck. When operating from a boat, the transducer or antenna is supported from the side of a boat. A skilled boat operator is required to maneuver near piers especially in rivers with high flow velocities. The best records are acquired when the boat's velocity is kept to a minimum. The slow speed reduces the amount of noise in the record, and expands the horizontal scale, which makes the geometry of the scour hole and subbottom reflectors easier to interpret from the data.

When operating from the shore, the equipment is set up on the bank of a river, and the transducer is slowly maneuvered near the piers by a person or cable. This set-up is used at sites with narrow rivers or where boat access is limited. When operating from a bridge deck, the equipment is set up in a vehicle or cart, which is wheeled across the bridge deck. A cable extends over the bridge deck to the transducer or antenna, which is guided by a person or cable. This set-up is used on low bridges where high-flow velocities or debris near piers and obstructions on the bridge do not pose a problem. When traversing upstream of the piers, better position control of the transducer can be obtained when operating from a boat or river bank than from a bridge deck.

Complete coverage of the areas that have the potential to scour is essential. Multiple cross-sections of data are usually collected at selected intervals along the upstream side of the piers. Data also are collected along the downstream side of the piers. Additional cross-sections are collected farther upstream and downstream to determine the extent of contraction scour, and lateral lines alongside the piers are collected to determine the lateral extent of the scour holes.

\section{Collection of Geophysical Data}

The Fathometer systems were the simplest to operate, most portable, and least expensive. The control unit usually was operated from a boat, but occasionally was operated from a bridge deck. Two people were required to conduct a Fathometer survey, and the Fathometer was usually used in conjunction with a more complex geophysical instrument. When operating from a boat, the transducer was either mounted on the hull of the boat or suspended rigidly from the side of 
the boat. When operating from a bridge deck, the transducer was attached to a sounding weight, lowered over the side of the bridge, and moved across the bridge to produce a bathymetric profile. Multiple lines of data along the upstream side of the piers were collected only when the Fathometer was operated from a boat. The location of the transducer was noted on the Fathometer record during data collection.

The fixed-frequency CSP system was more complex to operate than the Fathometer systems, and required a field crew of two or three people, including at least one trained individual. The equipment was operated from different-sized boats and from the banks of rivers. When operating from a large boat, the 150-lb transducer was suspended from the side of the boat by a fixed support. At small river sites and at sites where a boat launch was not available, a 12-ft inflatable boat was used. At these sites, the 150-lb transducer was suspended by a truck-tire inner tube and guided, but not supported, by the small boat. When operating the equipment from a river bank on narrow rivers, the transducer suspended by the inner tube was manually pulled across river.

The swept-frequency CSP systems were much heavier than the fixed-frequency systems, so swept-frequency data were not collected from the small boat. A minimum water depth of $2 \mathrm{ft}$ was required when using the swept-frequency system; this was because the boat required this depth, not the geophysical equipment. The swept-frequency CSP data were collected from a 22-ft Boston Whaler equipped with an over-the-side crane. The tow fishes were large and heavy and were suspended in the water alongside the boat by the crane. Eddy currents near piers made maneuvering near piers with this tow fish difficult. To change the frequency range, the transducers and tow fish had to be changed.

The GPR system was a little more complex to operate than the fixed-frequency
CSP system; but a survey could be conducted by a crew of two or three people, with at least one trained person. The GPR equipment was operated from large and small boats and on land across shallow or dry river channels. The antennas were floated alongside the boat as the boat maneuvered slowly upstream, downstream, and alongside the piers. An aluminum boat can interfere with the data when antennas are next to the boat, therefore, an inflatable or fiberglass boat was used to reduce this interference. In shallow streams or rivers, the antennas were pulled across scour holes by hand.

Two position-recording methods were used in this study - visual estimations and precise measurements collected with a laser-positioning system. At sites on narrow rivers with low-velocity water, where the transducer was manually pulled across the river, visual estimations of the transducer's location were noted on the field records. Locations of the beginnings of the lines, sides and center of piers, and the ends of the lines were noted on the records. At sites on large rivers or where future studies may require data to be re-collected along the same line, a position-recording system was used. Changes in water velocities caused by eddy currents near bridge piers made maneuvering at a constant velocity difficult. Because the boat travelled at different speeds, the horizontal scale of the geophysical record was distorted. Data from the laser-positioning system was used to correct the horizontal scale. That procedure is detailed in the processing section of this report.

\section{Collection of Verification Data}

Geophysical data were verified, if possible, by comparing them with physical measurements made at the site. Hard bottoms, soft bottoms, exposed footings, and less than $5 \mathrm{ft}$ of fill material can be detected in rivers less than $15 \mathrm{ft}$ deep by probing the bottom of the river with a 1-in. diameter hollow metal rod. The 
information obtained by probing was used to verify the interpretations of the geophysical data. Geophysical data interpretations also were compared with cores obtained at a site to confirm or identify subbottom interfaces. A vibracore system consisting of a concrete vibrator attached to a 3 -in. diameter 20 -ft long aluminum irrigation pipe with a core-catcher attached at its end was operated from a $22-\mathrm{ft}$ boat. The pipe was lowered to the river bottom through $7 \mathrm{ft}$ of water and was vibrated through about $9 \mathrm{ft}$ of bottom material. A 4-ft core was retrieved that confirmed the presence of a sand/clay interface at the bottom of an old scour hole that was detected by the geophysical techniques. The vibracore system is described in Thompson and others (1991), and its application in a scour hole is described in Haeni and Gorin (1989).

Subsurface lithologic logs at bridge sites and bridge plans also were used to help verify subbottom reflectors detected by the geophysical techniques. Although the lithologic logs did not provide scour data, they did provide information about the depth to geologic interfaces. This information confirmed the presence of geologic interfaces detected by geophysical techniques. It also confirmed that these interfaces were not caused by scour, but existed naturally before the bridge was built. The depths to footings obtained from the bridge plans were used to confirm the interpretation of footings in geophysical records.

\section{PROCESSING TECHNIQUES APPLIED TO SURFACE-GEOPHYSICAL AND POSITION DATA}

The application of digital-signal processing (DSP) techniques to surface-geophysical and position data improved the interpretation of unprocessed geophysical records (Haeni and Placzek, 1991; Haeni and others, 1992). The application of DSP routines to geophysical data sets increased the accuracy and ease of the data interpretations. These processing routines were not applied to every data set, however, because much of the unprocessed field data contained sufficient information to satisfy the goal of the survey. A geophysical record was processed if more information was required from the unprocessed field record or if a processing routine was being tested. Processing the data generally improved the records but did not provide information from a record if good data had not been collected initially.

Processed geophysical data were easier to interpret because horizontal scales and some of the geometry of geologic layers were corrected, noise and interference patterns were reduced in the data, and the resolution of the data display was improved. Position information was used to correct for differences in the speeds and paths of the boats and to produce a geophysical profile with a horizontally corrected scale. Digital band-pass filtering routines eliminated some system and environmental noise from the field data sets, and a predictive-deconvolution algorithm improved the display resolution of some records. A Kirchoff migration algorithm applied to horizontally corrected data sets corrected the geometry of the bottom of the scour holes and reduced interference patterns from point reflectors, piers, or rip-rap bottoms.

\section{Fathometer and Position Data}

Fathometer and position data were processed using a PC after data collection. Position and depth data acquired using the Hydro I data logger were transferred from the data logger, through a standard RS-232 serial link, to a PC. Position and depth data acquired using the Hypack software were automatically saved to an ASCII file on the PC. The Hydro I and Hypack software were used to edit the data, and Isomate and Surfer were used to create contour plots from the edited data. 
The Hydro I hydrographic software was used after data collection to graphically edit, display, and print two-dimensional bathymetric and trackline plots. First, the software was used to review bathymetric plots and tracklines and edit or remove any obviously erroneous data points. Erroneous data points were identified because they were extremely large or small compared with nearby data points. Erroneous position data were caused by the laser missing the target on the boat and by radio interference during data transmission from shore to ship. Incorrect depth data were obtained when the Fathometer digitized a depth that was not the water bottom, in which case the analog chart record was reviewed to determine the correct depth. After the individual tracklines and depths were edited, two-dimensional plots of the individual tracklines and bathymetric profile data were printed. An example of an edited twodimensional bathymetric profile printed using the Hydro I software is shown in figure 2.

The Hypack software package was used to monitor bathymetric and trackline plots during data collection and to graphically edit and print two-dimensional plots after data collection. Isomate, an optional software module to Hypack, was used to create a twodimensional contour plot of the data. First, multiple lines of the data were combined into a single grid file used to create the contour map. For example, three lines of data upstream from a pier, a line downstream and a line alongside the pier were combined into a single grid file.

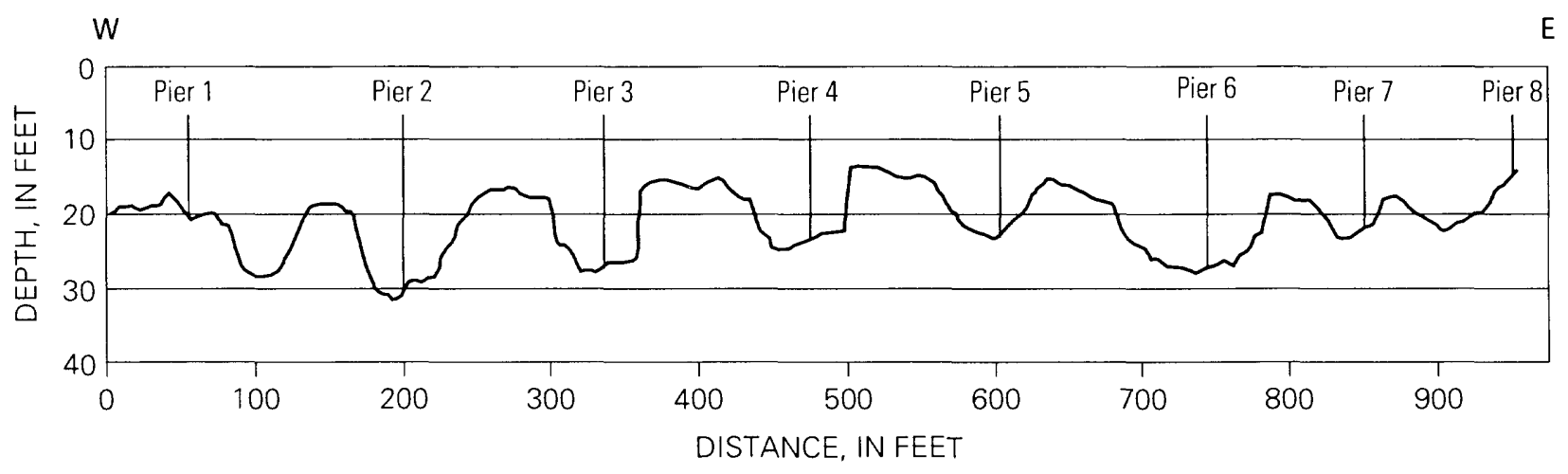

Figure 2. Positioned 200-kilohertz Fathometer cross-section 5 feet upstream from the piers at the Bulkeley Bridge, Hartford, Conn. (Modified from Haeni and others, 1992.) 
The grid size selected during the gridding process determined the spatial resolution of the plot. A grid size of $5 \mathrm{ft}$ indicates that the survey area was divided into 5-ft square blocks and a single depth was determined for each block. If a depth measurement was not available for a block of the grid, the program interpolated a depth value for that block from surrounding depth measurements. From the completed grid file, a plot file was created from which a printout of the contour data was made. From the grid file, Isomate also can create a DXF file, which can be used in many computer-aided design (CAD) packages to display, enhance, and print data.

Surfer (version 4.15), by Golden Software, Inc., was used to edit, display, and print two- and three-dimensional plots of the position and depth data. Surfer uses a numerical rather than graphical editor, so typically, data were edited using the Hydro I software or Hypack and then transferred to Surfer. Grid and plot files were created by Surfer in a similar way as with Isomate. In addition to twodimensional contour plots, Surfer also produced three-dimensional surface and contour plots (fig. 3). Surfer 4.15 can use only 14,000 $\mathrm{x}-\mathrm{y}-\mathrm{z}$ data points per plot, but the version of Surfer for Windows can use more than 250,000 data points per plot when used on a $\mathrm{PC}$ with $8 \mathrm{MB}$ of RAM. More data points can be used if the amount of RAM is increased.

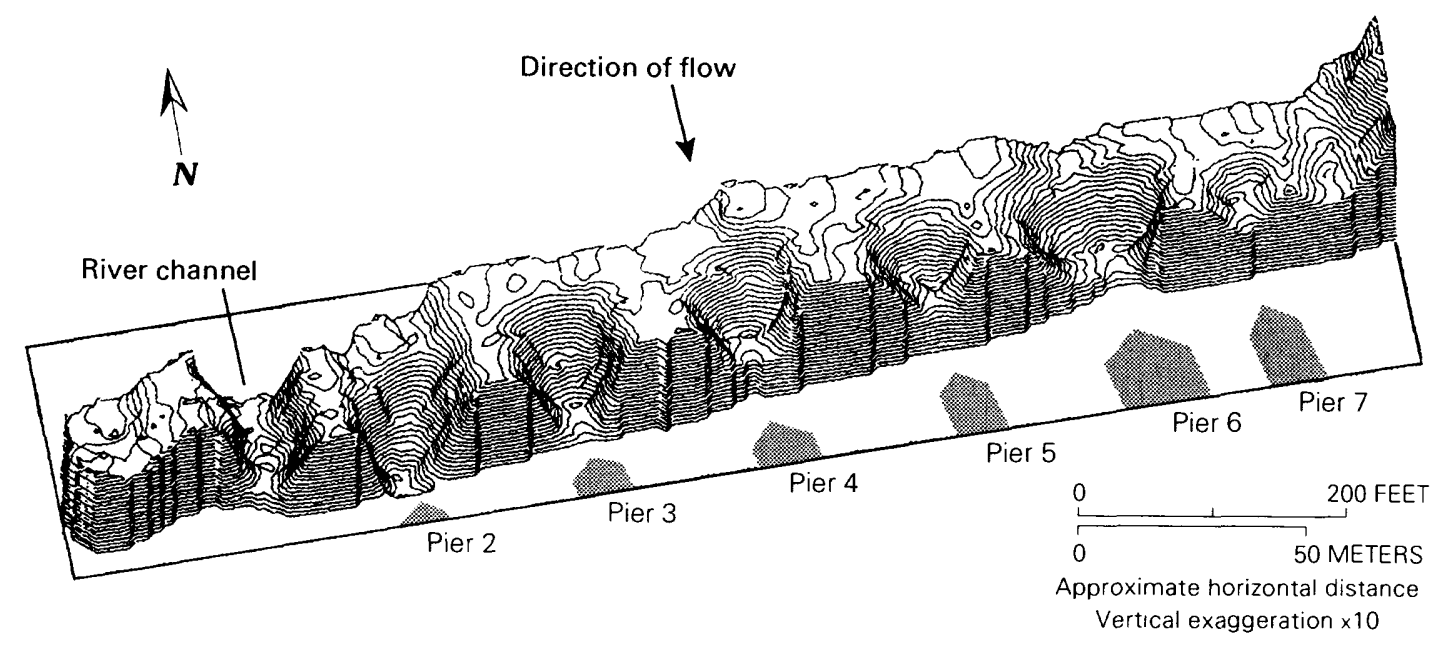

Figure 3. Three-dimensional bathymetric contour plot upstream from the Bulkeley Bridge, Hartford, Conn. (Modified from Haeni, 1992.) 


\section{Color Fathometer and Continuous Seismic-Reflection Profiling Data}

Recorded color Fathometer and CSP data were transferred to a $\mathrm{PC}$ and processed using the same hardware and software. A commercially available $100-\mathrm{kHz}$ analog to digital (A/D) converter card (DT2823 from Data Translations) was used in an IBM-compatible 80386-based PC to transfer the data. DATIN, a program written by the USGS, controlled the operation of the A/D card during the datatransfer procedure. DISPLAY, a program also written by the USGS, was used to display and print the data on a Hewlett Packard PaintJet printer. RADAN3, a commercially available program written by GSSI, was used to process, display, and print the data. RADPRINT, also written by GSSI, was used to display and print the data on a printer supported under Windows.

The color Fathometer and CSP systems stored a data signal and a trigger signal on a DAT cartridge. The data signal from the DAT cartridge was demodulated, amplified, and filtered before it was input into the $\mathrm{A} / \mathrm{D}$ card. The trigger signal was demodulated, and its pulse width was shortened before it was input into the $\mathrm{A} / \mathrm{D}$ card. DATIN controlled the transfer of these signals through the A/D card to a binary file on a hard drive. Each time a transducer sounded, an individual data trace and its corresponding trigger pulse were recorded on the tape. Each individual data trace transferred to the PC by DATIN was represented by 1,024 16-bit samples. The sampling rate, record length, and the number and size of buffers used during the transfer process were selected by the user. These variables determined the datatransfer rate, which was kept below $512 \mathrm{kB} / \mathrm{s}$, the limit of the optimized hard drive. The sampling rate determined the highest frequency component that could be preserved during the transfer process. The sampling rate always was set to at least twice the highest frequency component contained in the filtered data. The record length, equivalent to the total two-way travel time, determined the maximum depth represented by the data.

To transfer data from the Color Fathometer to a PC, the data were replayed through the color Fathometer system from the DAT cartridge, and data and trigger signals were simultaneously input into the A/D card. In one instance, 2 minutes of color Fathometer data contained 720 traces. After applying a $20-\mathrm{kHz}$ low-pass filter to each trace, each trace was sampled at $42 \mathrm{kHz}$ for $24 \mathrm{~ms}$ and was represented by 1,024 16-bit samples. The transfer process required a data transfer rate of $13 \mathrm{kB} / \mathrm{s}$, the size of the data file was $1.48 \mathrm{MB}$, and the file included data to a depth of $60 \mathrm{ft}$.

Once transferred to a PC, the color Fathometer data were displayed as a color amplitude plot and printed using DISPLAY. DISPLAY allowed display parameters, such as the color palette, color threshold levels, and vertical scale to be adjusted. Periodic wiggle traces were plotted over the color amplitude plot to provide more detailed amplitude and phase information about individual traces. The tops and bottoms of records were eliminated to focus on particular features of a scour hole.

To transfer recorded 3.5, 7.0, and 14.0$\mathrm{kHz}$ CSP data to a PC, data were replayed through the CSP system from a DAT cartridge and data and trigger signals were input into the A/D card. In one instance, 2 minutes of 14$\mathrm{kHz}$ CSP data contained 1,044 traces. After applying a $28-\mathrm{kHz}$ low-pass filter to each trace, each trace was sampled at $68.3 \mathrm{kHz}$ for $15 \mathrm{~ms}$ and was represented by 1,024 16-bit samples. The transfer process required a data transfer rate of $17.9 \mathrm{kB} / \mathrm{s}$, the size of the data file was $2.14 \mathrm{MB}$, and the file included data to a depth of $37 \mathrm{ft}$.

The CSP data file created by DATIN was then converted to a file that was read by RADAN3 and processed by RADAN3. Digital filtering, rubber sheeting, predictive deconvolution, and migration processes were applied 
to the CSP data. Horizontal digital filtering eliminated some noise in the record caused by transducer ringing and also eliminated flat reflectors. Vertical digital filtering narrowed the band-pass region of the signal, therefore, it reduced some ambient noise caused by the system or the boat's engine. A rubber-sheeting technique used position data to correct the horizontal scale of the geophysical profiles.

Unevenly spaced marks made on the geophysical record by the positioning system representing $10 \mathrm{ft}$ of boat travel indicated that the boat's velocity was not constant. Rubber sheeting corrected for the inconsistent velocity by interpolating or deleting traces to evenly space the marks. A predictive-deconvolution algorithm improved the resolution of the display by narrowing the displayed width of reflected signals caused by single reflectors. A Kirchoff migration algorithm geometrically corrected the record by collapsing hyperbolas in the record caused by side echoes or boulders on the river bottom to the location of their sources. In addition, the slope of the sides of a scour hole were migrated to their actual shape. An unprocessed 14-kHz CSP record from the Bulkeley Bridge is shown in figure 4 and the same record, after having been digitally filtered, rubber sheeted, and deconvolved, is shown in figure 5. The fil- tering reduced some noise, the rubber sheeting improved the geometric representation of the shape of the hole, and the deconvolution algorithm resolved thin layers of fill material representing possible past scour surfaces.

The swept-frequency CSP systems incorporated signal processing techniques into their control units that automatically deconvolved the signal pulse during data collection. Additional processing of the data was done in real time and the processed data were displayed and printed as they were collected. The Precision Signal system used a Sparc II workstation to handle the intensive DSP routines requiring real-time digital filtering and deconvolution. The DataSonics system used an 80386 microprocessor and had similar data-processing capabilities.

Horizontal-scale corrections and migration routines were not applied to the sweptfrequency data because positioning information was not collected while testing these systems. Although possible, sweptfrequency data were not transferred to a $\mathrm{PC}$ to be processed for this study. A gray-scale swept-frequency record collected at the Baldwin Bridge with a Precision Signal system is shown in figure 6 . 


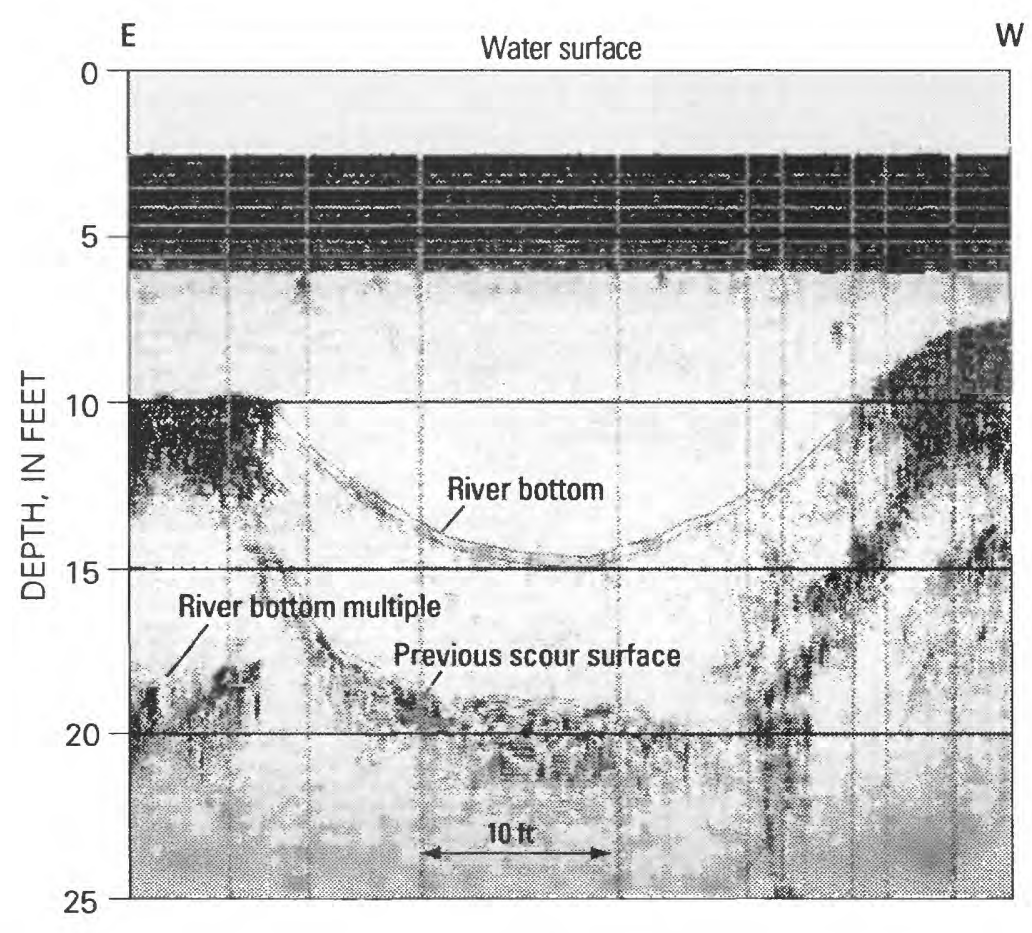

Figure 4. Unprocessed positioned 14-kilohertz continuous seismic-reflection profiling data collected 10 feet upstream from pier 4 of the Bulkeley Bridge, Hartford, Conn. (Modified from Haeni, 1992.)

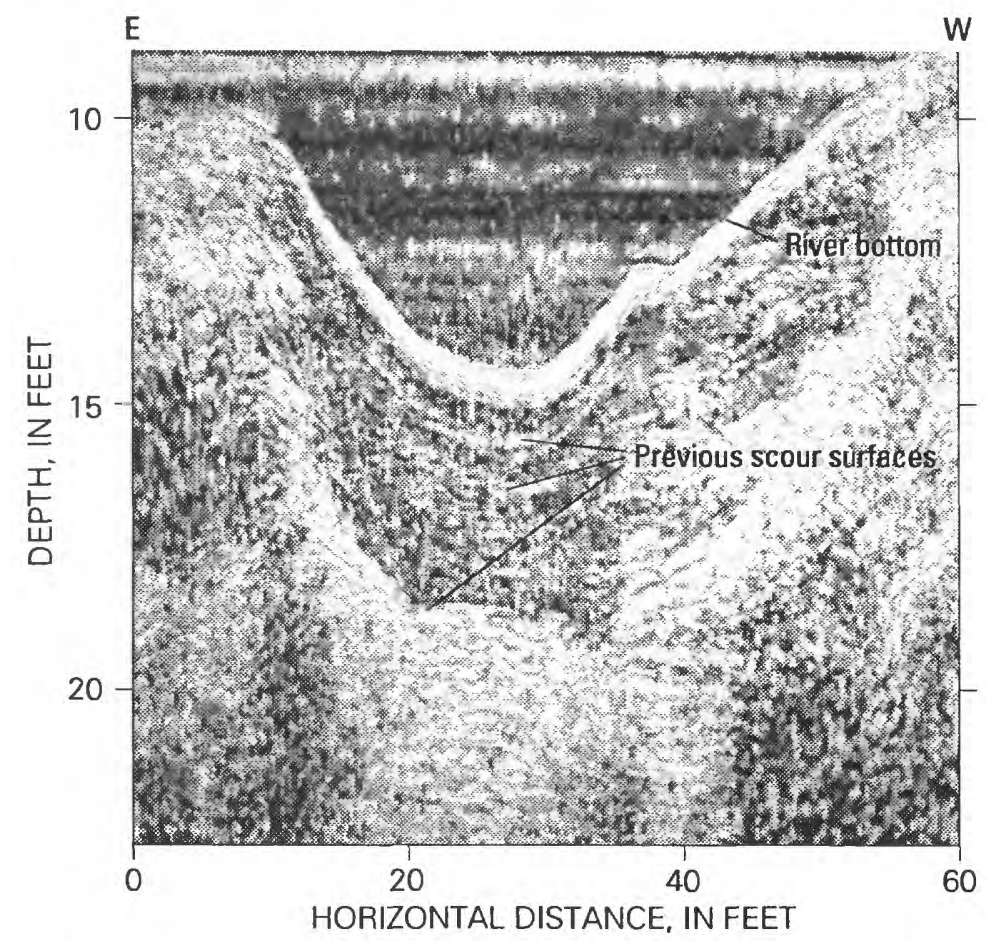

Figure 5. Digitally filtered, horizontally corrected, deconvolved 14-kilohertz data from figure 4. 


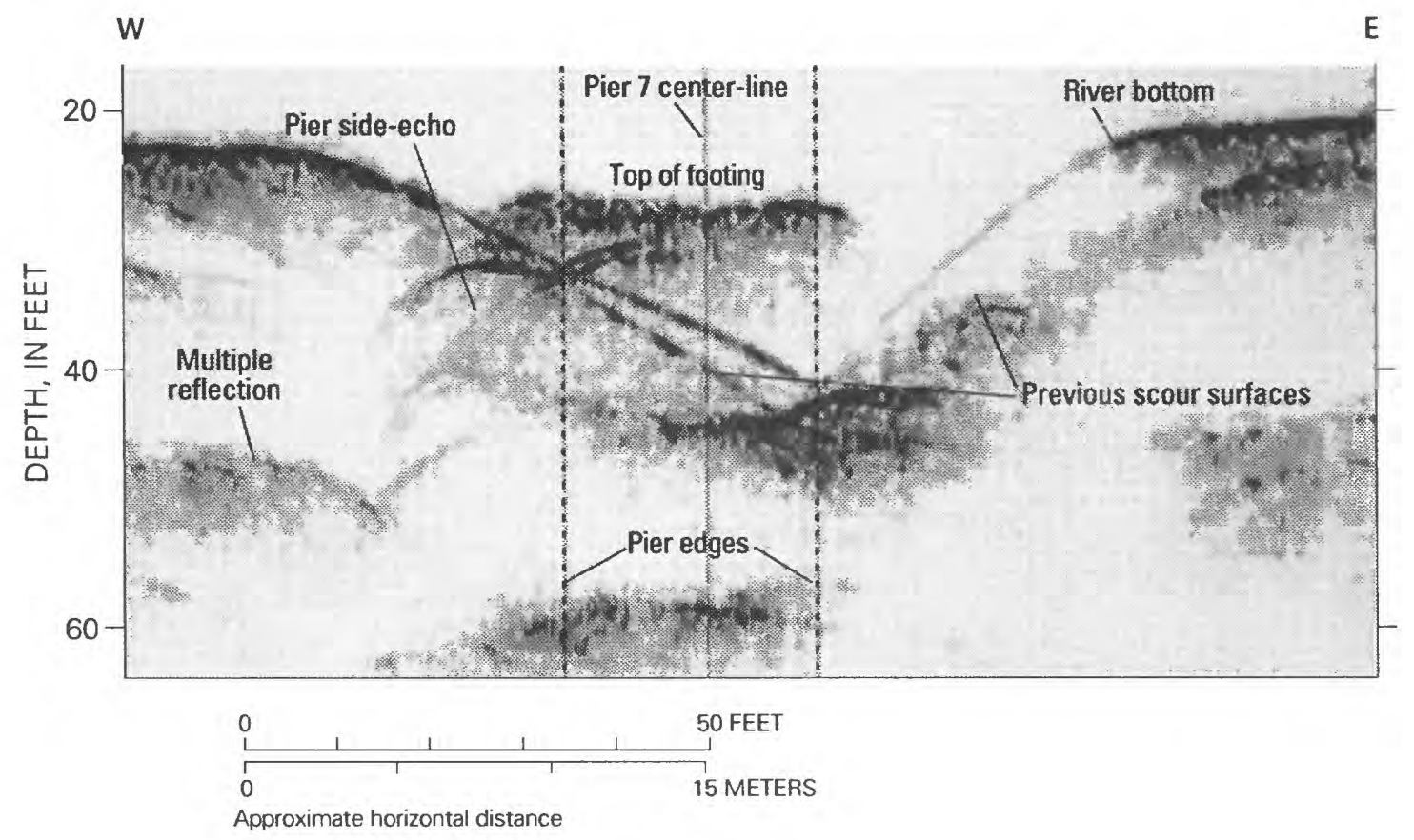

Figure 6. Gray-scale amplitude plot of 2- to 16-kilohertz swept-frequency record collected 10 feet upstream from pier 7 at the new Baldwin Bridge, Old Saybrook, Conn. (after construction).

\section{Ground-Penetrating Radar Data}

GPR data recorded on $3 \mathrm{M}$ data cartridges were transferred to a PC and processed. A commercially available tape drive read the $3 \mathrm{M}$ data cartridges, and READTAPE, a USGS program, was used to transfer the radar data to a file that could be read by RADAN3. Digital filtering, rubber sheeting, deconvolution, and migration processes were applied to the GPR data using RADAN3. An example of an unprocessed GPR record from the Route 14 bridge in Canterbury, Conn., is shown in figure 7. The wiggle-trace plot of the same record, after applying a band-pass filter and a migration routine, is shown in figure 8 . The hyperbolas on the river bottom east of the pier have been collapsed to their point of origin.

Care was used when the radar profiles were migrated and interpreted, because at least two signal velocities were present. Table 2 shows that the electromagnetic energy velocity is approximately $0.11 \mathrm{ft} / \mathrm{ns}$ in freshwater and is approximately $0.18 \mathrm{ft} / \mathrm{ns}$ in saturated sand. A fully migrated section must use both of these velocities. The migration routine in RADAN3 uses only one velocity. The velocity in water was used, therefore, only the water/sediment interface was correctly migrated, and reflectors in the subbottom were not interpreted as correctly migrated. 


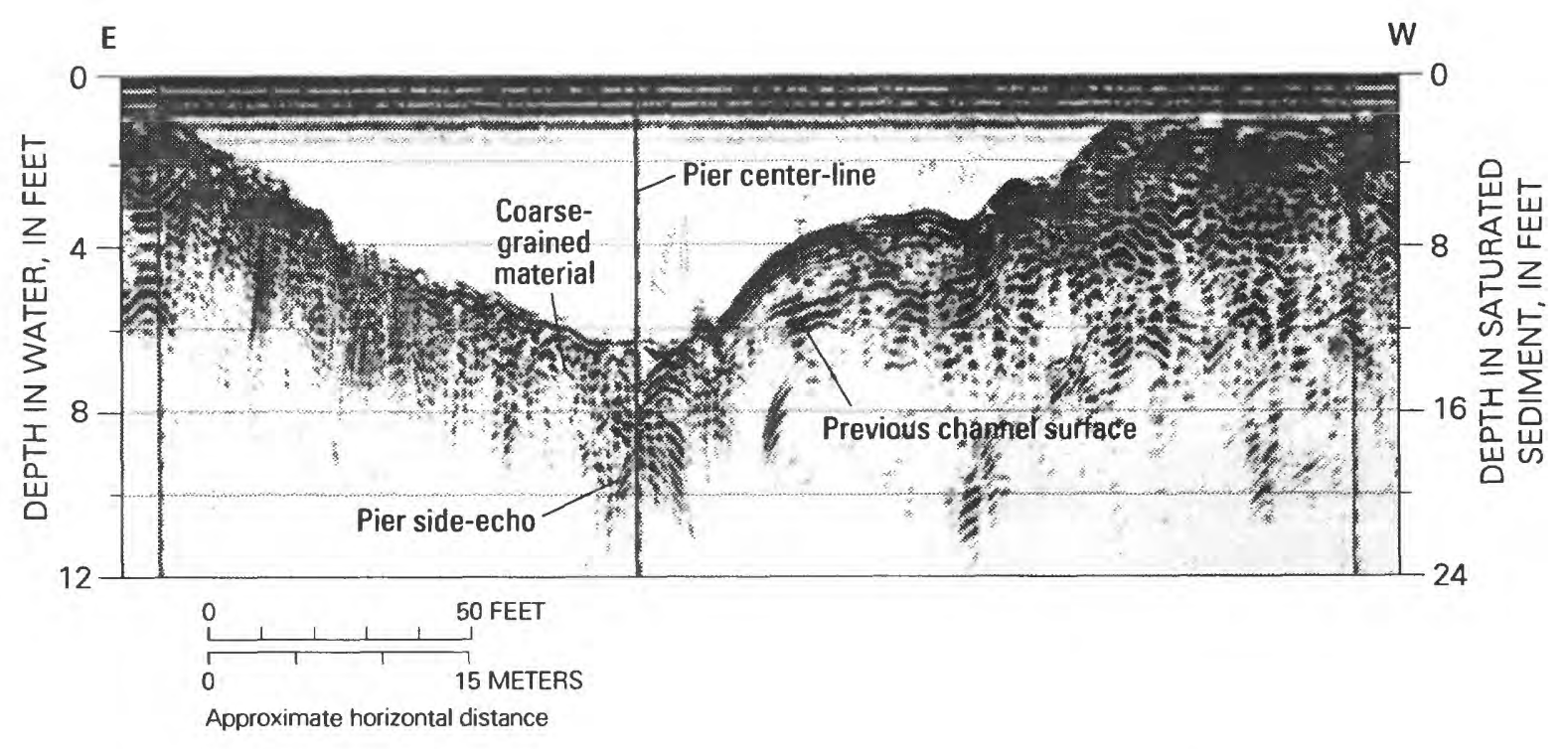

Figure 7. Unprocessed 300-megahertz ground-penetrating radar data collected 2 feet upstream from the pier at the Route 14 bridge in Canterbury, Conn.

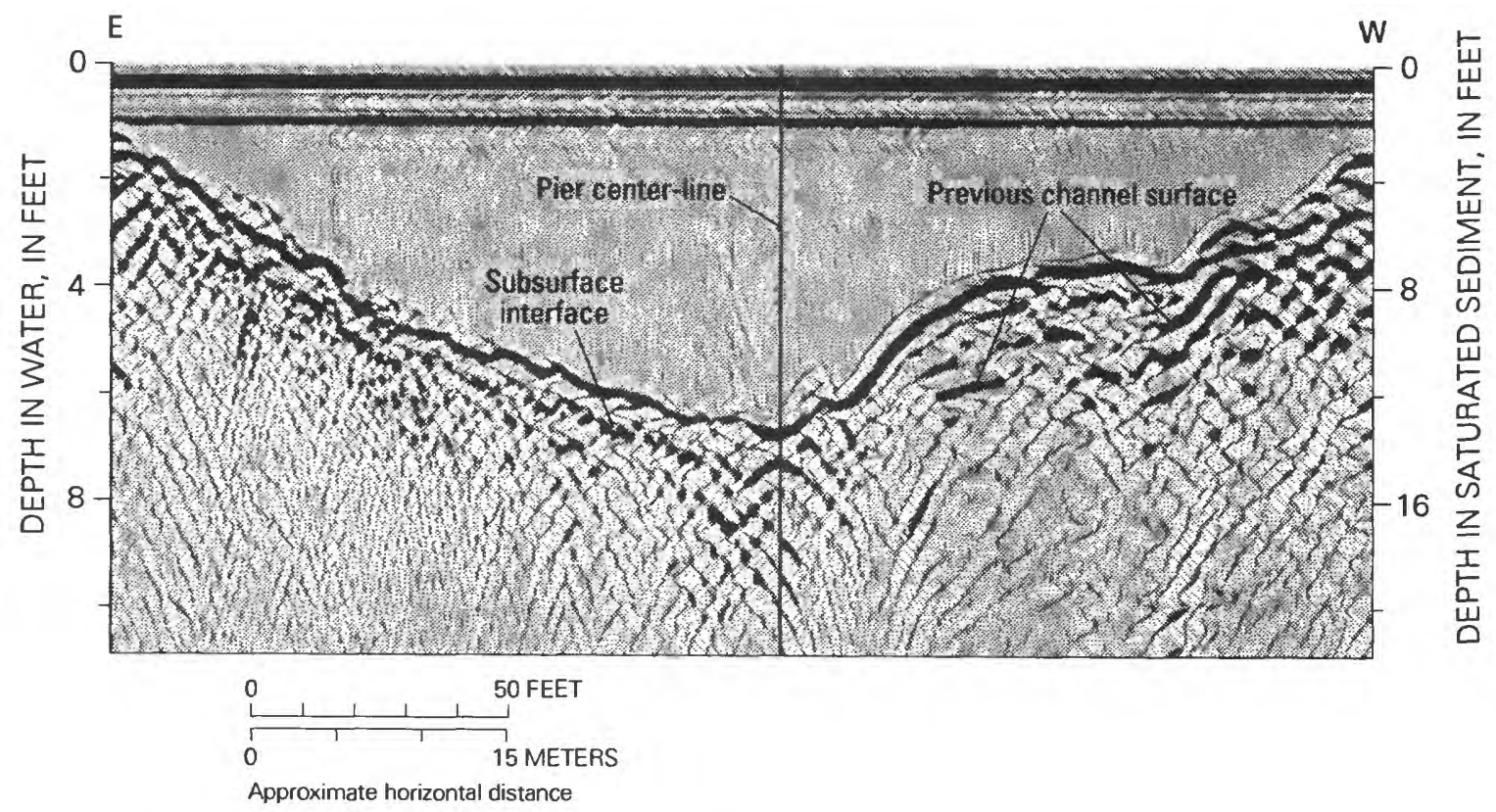

Figure 8. Wiggle-trace plot of digitally filtered and migrated 300-megahertz groundpenetrating radar data from figure 7. 


\section{RESULTS OF SURFACE- GEOPHYSICAL TECHNIQUES AT SELECTED BRIDGE SITES}

Geophysical data were collected at six bridge sites in Connecticut (fig. 1). The sites were chosen because of their different physical settings and potential for scour. The river at each site ranged from 200 to $1,800 \mathrm{ft}$ wide and from less than 1 to $40 \mathrm{ft}$ deep. The specific conductance of the water ranged from 64 to $40,000 \mu \mathrm{S} / \mathrm{cm}$. The bottom and subbottom materials also were different from site to site. The number of piers in the water ranged from 1 to 8 . The sites were chosen so that the utility of each geophysical technique applied in different physical settings could be assessed.

The Bulkeley Bridge and the Baldwin Bridge sites were chosen as primary test sites, where new or modified instrumentation and new data collection and interpretation methods were tested during this study. These two sites were chosen because historic surface-water flow records, complete copies of bridgeconstruction plans, and a complete set of standard geophysical records were available. A USGS streamflow-gaging station at the Bulkeley Bridge provided historic discharge measurements of the Connecticut River since 1905. A USGS streamflow-gaging station near Middletown (20 mi north of the Baldwin Bridge) provided historic discharge measurements of the Connecticut River Estuary since 1965. Bridge-construction plans, including test lithologic logs, were available at both sites, and cores were collected in a scour hole at the Bulkeley Bridge site (Haeni and Gorin, 1989). Data collected with new or modified equipment and techniques were evaluated by comparing the data with the standard data sets.

\section{Old Baldwin Bridge, Old Saybrook}

The Old Baldwin Bridge carried Interstate 95 over the 1,800 -ft wide Connecticut River Estuary near Old Saybrook, Conn. and had eight round-nose piers spaced about $230 \mathrm{ft}$ apart. The piers in the saltwater estuary were numbered from 2 to 10 (west to east) to correlate with Connecticut Department of Transportation bridge plans. The average water depth across the section was $20 \mathrm{ft}$, and a $40-\mathrm{ft}$ deep channel was between piers 8 and 9 . Because of tidal influence at this site, flow reversal occurs. The river level fluctuates within a 4-ft range during a full tidal cycle, and depth scales were corrected for varying tidal stages. A maximum discharge of $186,000 \mathrm{ft}^{3} / \mathrm{s}$ was recorded on June 2, 1984 near Middletown (Cervione and others, 1992). The river at this site has a mud bottom and a sand and silt subbottom (Bingham and others, 1975, p. 48; Horne and Patton, 1989). Unpositioned 3.5$\mathrm{kHz}$ CSP, 20-kHz color Fathometer, and 200$\mathrm{kHz}$ Fathometer data were collected at the site in May 1989. GPR data were not collected at this site because saltwater prevented the effective use of this technique.

The $200-\mathrm{kHz}$ Fathometer data collected $10 \mathrm{ft}$ upstream from the piers indicated the presence of scour holes near piers 4 through 9 and a 40-ft deep channel between piers 8 and 9 (fig. 9). The largest scour hole detected was located at pier 8 and was estimated to be $10 \mathrm{ft}$ deep. Interference from echoes from the footing prevented an interpretation of the actual bottom of this hole from the Fathometer record.

The $3.5-\mathrm{kHz}$ CSP data collected simultaneously indicate the same bottom features as the Fathometer but contained some subbottom information. At pier 8 (fig. 10), many hyperbolic reflectors near the bottom of the hole indicate that coarse material, such as gravel, is present. A 2-ft thick layer of fill material is interpreted along the east side of the hole. A 2-ft thick layer of fill material also was detected at pier 7. At this site, the CSP technique was able to detect the river bottom and the thickness of the fill material on the east side of the holes at piers 7 and 8, whereas the Fathometer could not detect the fill material. The setting of this site was favorable for the CSP technique although interference from side echoes was present in the data. 


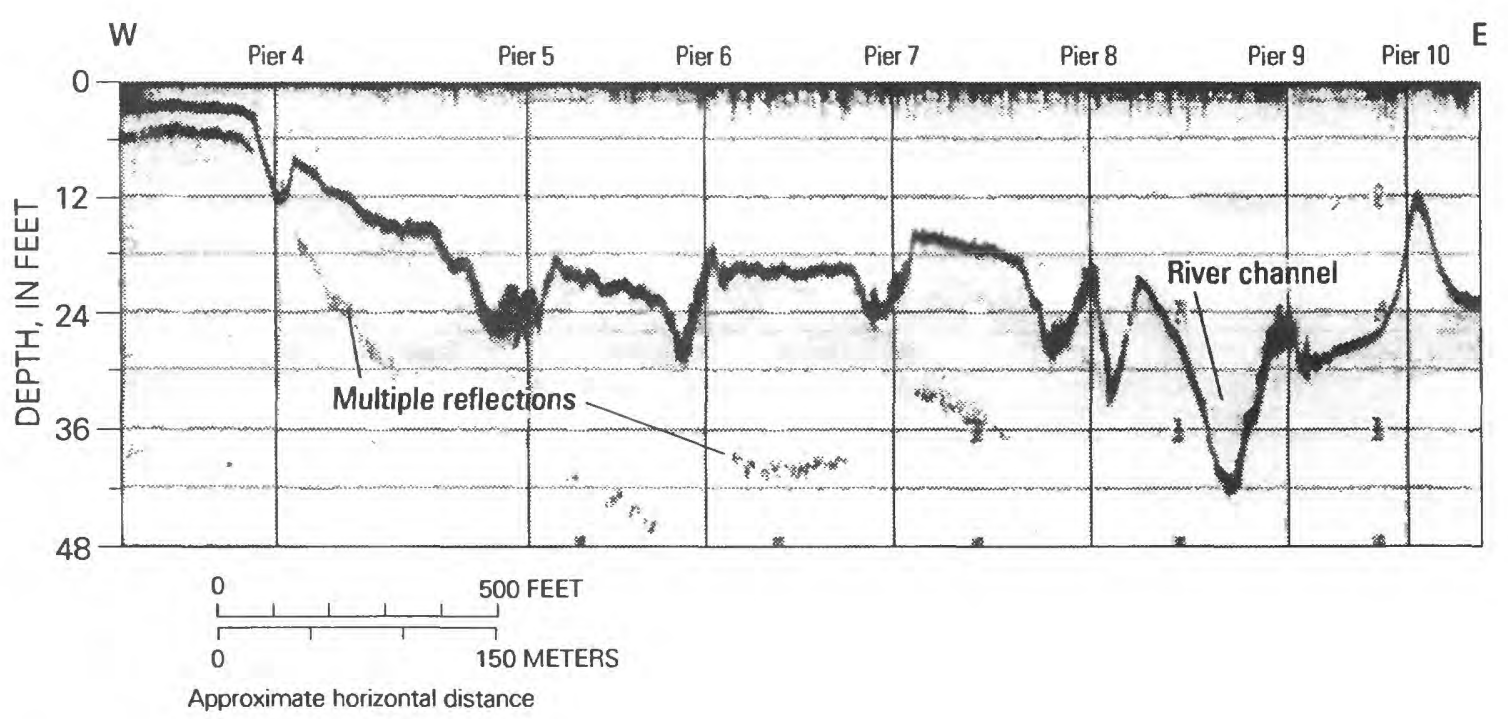

Figure 9. Unpositioned 200-kilohertz Fathometer profile collected 10 feet upstream from the piers at the old Baldwin Bridge, Old Saybrook, Conn.

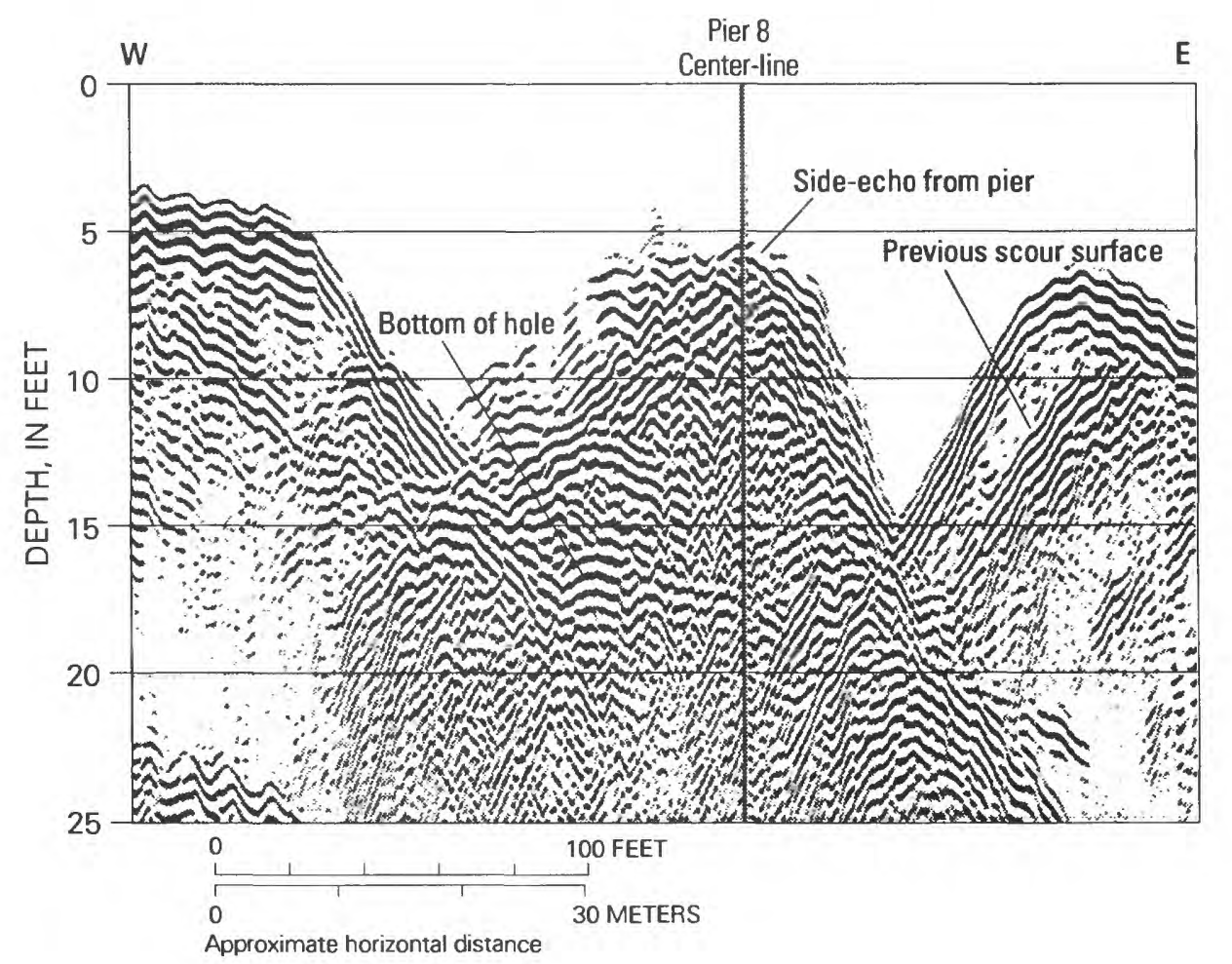

Figure 10. Unpositioned 3.5-kilohertz continuous seismic-reflection profiling data collected 10 feet upstream from pier 8 at the old Baldwin Bridge, Old Saybrook, Conn. 


\section{New Baldwin Bridge, Old Saybrook}

The new Baldwin Bridge, constructed $60 \mathrm{ft}$ south of the old Baldwin Bridge, now carries Interstate 95 over the Connecticut River Estuary (fig. 11). Geophysical data were collected at the new bridge location before, during, and after construction (Placzek and others, 1993). The new bridge has eight rounded-nose piers spaced $240 \mathrm{ft}$ apart in water ranging from 10 to $40 \mathrm{ft}$ deep. Each pier consists of two columns, each $8 \mathrm{ft}$ wide and $36 \mathrm{ft}$ long. The piers in the water were numbered 3 to 9 (west to east) to correlate with Connecticut Department of Transportation bridge plans. A navigation channel is between piers 8 and 9, and a wood fender system is in place alongside those piers. During construction, each pier was protected by a rectangular cofferdam that was $36 \mathrm{ft}$ wide and $144 \mathrm{ft}$ long; the flow of the river was perpendicular to the $36-\mathrm{ft}$ side. After construction, each cofferdam was cut off at the riverbed level or the top of the footing, whichever was higher.

Since construction began on this bridge, the maximum discharge of the Connecticut River near Middletown (the closest USGS streamflow-gaging station) was $94,000 \mathrm{ft}^{3} / \mathrm{s}$ on March 22, 1990 (Cervione and others, 1991). This discharge represents a peak flow equivalent to a 3-year recurrence-interval flood; therefore, no significant floods have occurred since the construction of this bridge.

Fathometer and CSP data were collected before, during, and after the construction of the new Baldwin Bridge. The specific conductance of saltwater is 40,000 $\mu \mathrm{S} / \mathrm{cm}$ (table 2), so GPR techniques were not used at this site. This bridge was under construction from 1990-91, and unpositioned Fathometer and 3.5- and 7-kHz CSP data were collected on May 25, 1989; October 31, 1990; July 22, 1992; and December 15, 1992. Unpositioned swept-frequency CSP data, positioned Fathometer, and positioned $7-\mathrm{kHz}$ CSP data were collected on May 18, 1993. Approximate horizontal scales were determined for the unpositioned records by correlating visually estimated positions with bridge plans. Before construction of the new bridge, the data were collected along the proposed bridge alignment, and the centerlines of the old bridge piers were marked on the record. The new piers are located $50 \mathrm{ft}$ west of the corresponding old piers. During construction, the sides of the cofferdams were marked on the record; after construction, the center-lines of the new piers were marked on the records.

Fathometer data collected along the proposed bridge alignment before construction (fig. 12) show an undulating river bottom with about $6 \mathrm{ft}$ of relief, a flat river bottom at the proposed pier 7 location, and a $40-\mathrm{ft}$ deep navigation channel east of the proposed pier 8 location. The 7-kHz CSP data collected before construction show subbottom reflectors from geologic layers up to $25 \mathrm{ft}$ deep. This information was collected before bridge construction so the geologic layers could be identified in future records and would not be interpreted as scour surfaces.

Fathometer data collected $15 \mathrm{ft}$ upstream from the piers during construction (fig. 13) show scour holes $5 \mathrm{ft}$ deep at pier 6 , $11 \mathrm{ft}$ deep at pier 7 , and $7 \mathrm{ft}$ deep at pier 8 . The 7-kHz CSP data collected simultaneously did not detect any fill material in these scour holes. Fathometer data collected $15 \mathrm{ft}$ upstream from the piers after construction (fig. 14) show no scour hole at pier 6 , and scour holes $21 \mathrm{ft}$ deep at pier 7 and $15 \mathrm{ft}$ deep at pier 8 . The top of the footings also were detected on the records at piers 7 and 8 . The deepest scour hole downstream from the piers was $4 \mathrm{ft}$ deep at pier 7. The $3.5-\mathrm{kHz}$ CSP data collected $15 \mathrm{ft}$ upstream from the piers after construction (fig. 15) show that $5 \mathrm{ft}$ of material was deposited in the scour hole at pier 6 and the scour holes near piers 7 and 8 increased in depth, but had 


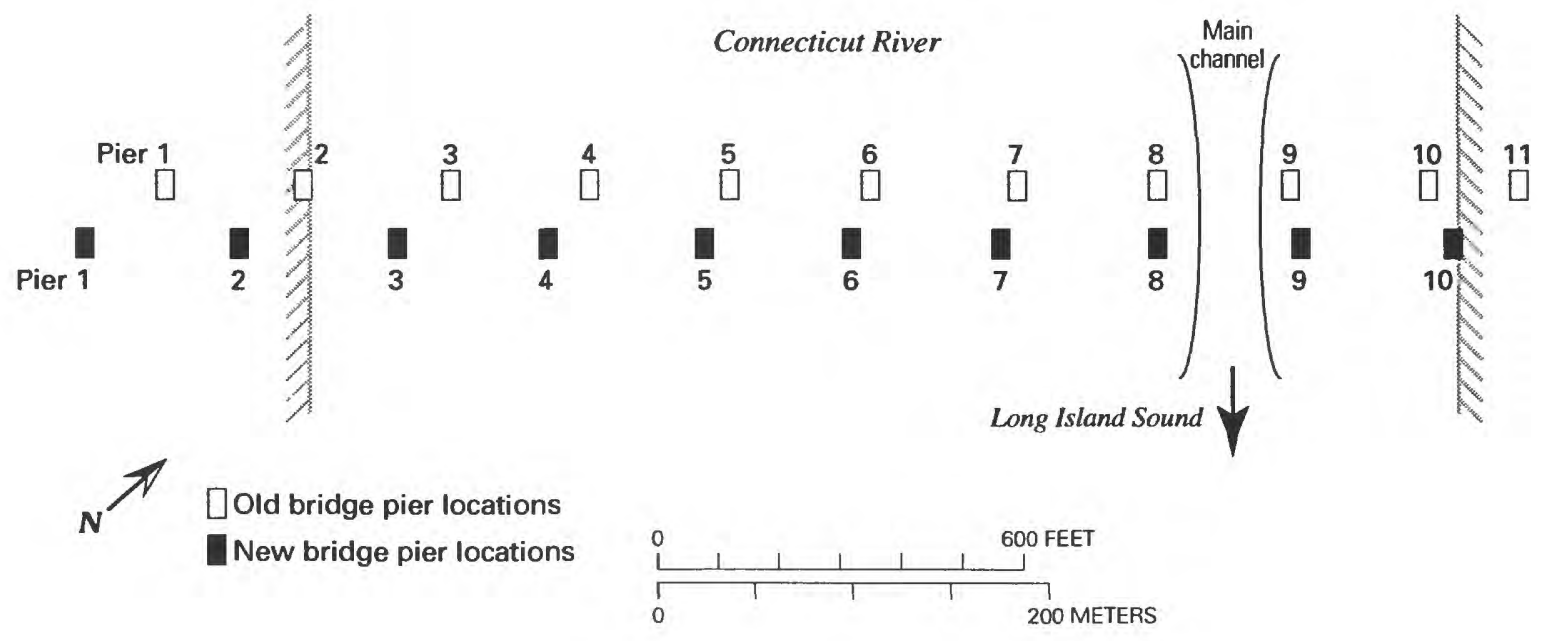

Figure 11. The old and new Baldwin Bridge pier locations, Old Saybrook, Conn. 


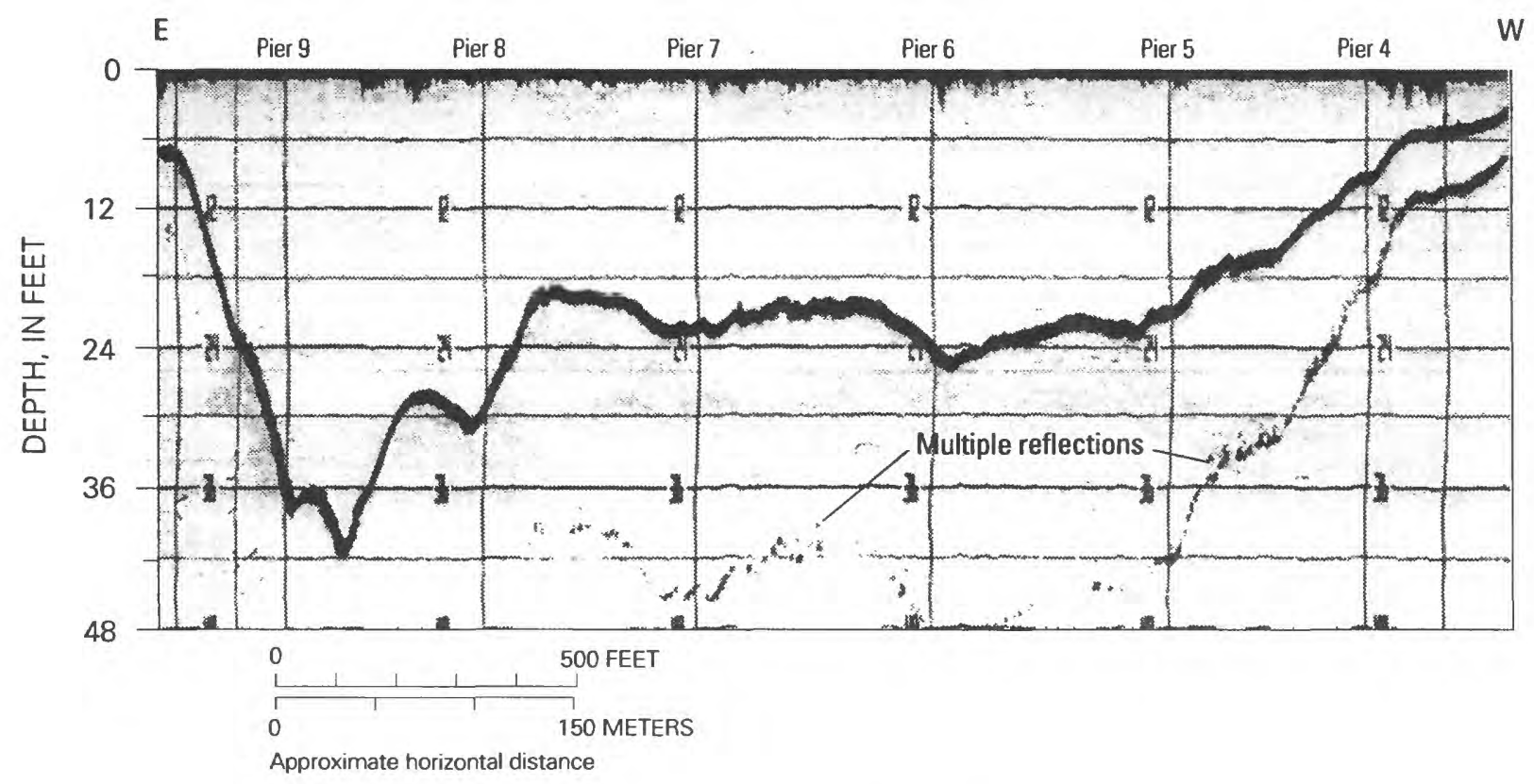

Figure 12. Unpositioned 200-kilohertz Fathometer profile collected along the proposed bridge alignment of the new Baldwin Bridge, Old Saybrook, Conn. (before construction).

no fill material in them. Side echoes from the piers were present in the record but did not interfere with the interpretation of the data. The tops of the footings at piers 7 and 8 also were detected. CSP data on the downstream side of the piers show geologic layers in the subbottom but no filled scour holes.

Additional Fathometer data were collected laterally alongside old and new pier 7 on December 15, 1992. This line extended from $350 \mathrm{ft}$ north of the old bridge to $250 \mathrm{ft}$ south of the new bridge - $10 \mathrm{ft}$ east of both piers. Scour depths of $5 \mathrm{ft}$ upstream from old pier 7 and $20 \mathrm{ft}$ upstream from new pier 7 were detected. Footings on the sides of both piers were detected on the record. Little or no scour was observed on the south side of either pier.

The single-element $14-\mathrm{kHz}$ CSP transducer produced poor-quality records at the new Baldwin Bridge, but the new dualelement $14-\mathrm{kHz}$ CSP transducer using the active ring-damping circuit produced improved records. Data collected in December 1992 using the new transducer and circuit detected a thin, 1- $\mathrm{ft}$ layer of fill material along the west side of the scour hole at pier 7 (fig. 16). A deeper previous scour surface also was present in this record on the west side of the hole. The east side of the hole contained many hyperbolic reflections indicating that it may be armored with gravel or rip-rap. Multiple reflections, side echoes from the piers, and an echo from the top of the sheet piling or footing also appear in the record.

Positioned 7-kHz CSP and 2- to 16$\mathrm{kHz}$ swept-frequency CSP data, collected in May 1993, detected the same deeper layer of fill material on the west side of the hole at pier 7. The high-resolution swept-frequency CSP data (fig. 6) also show the 1-ft thick layer of fill material on the west side of the hole. No additional fill material was detected in the other scour holes. 


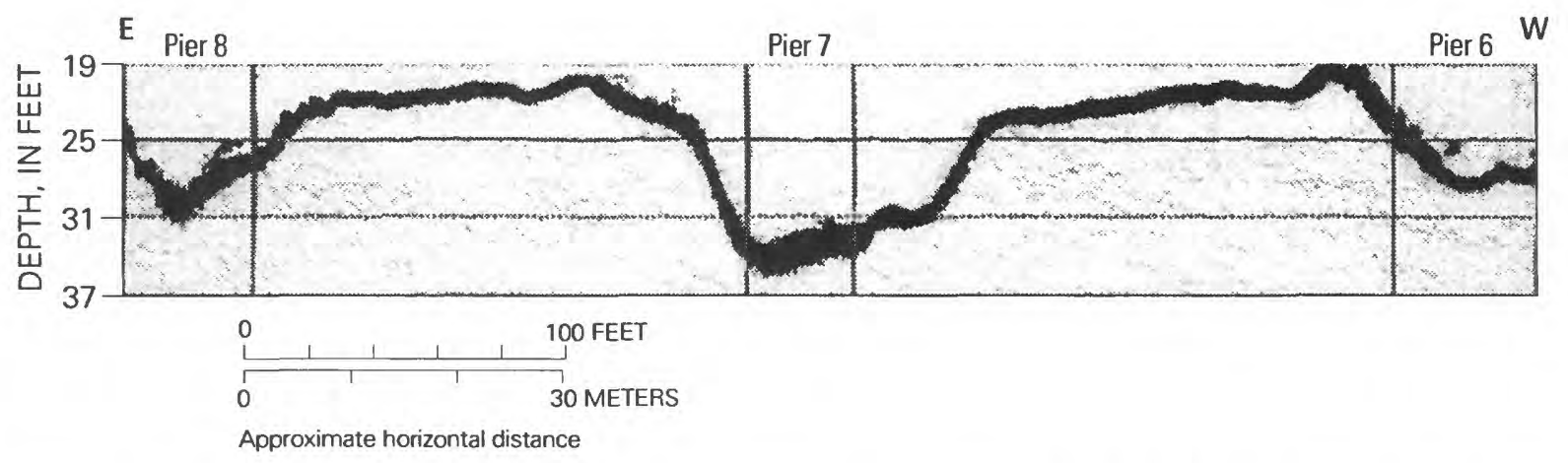

Figure 13. Unpositioned 200-kilohertz Fathometer data collected 15 feet upstream from the new Baldwin Bridge, Old Saybrook, Conn. (during construction). (From Placzek and others, 1993.)

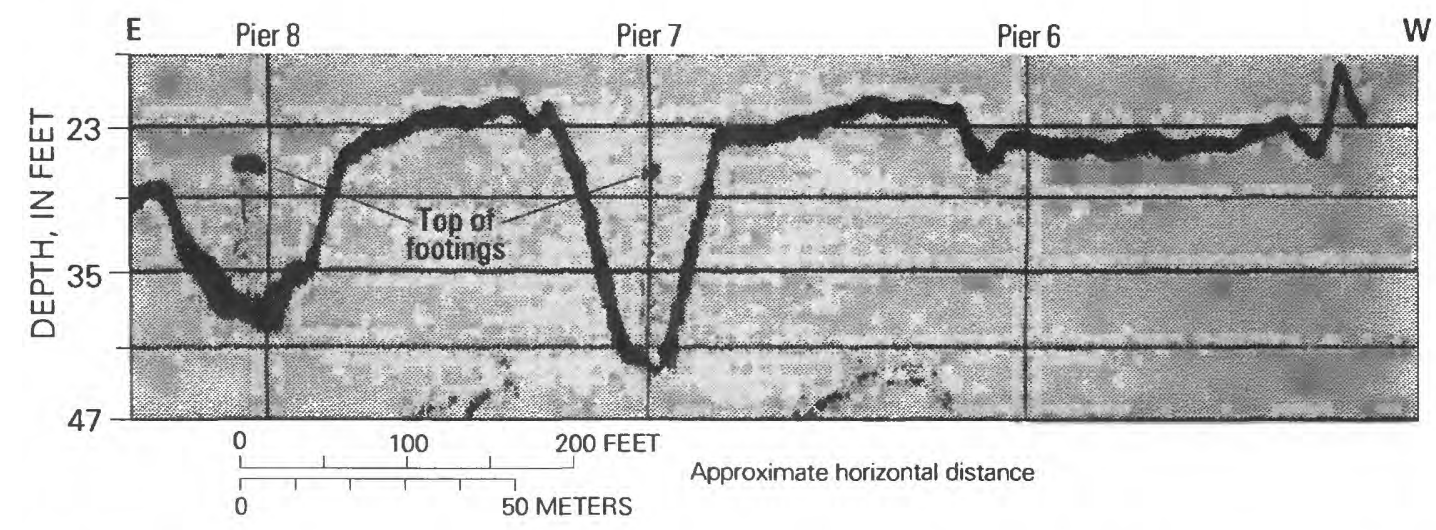

Figure 14. Unpositioned 200-kilohertz Fathometer data collected 15 feet upstream from the new Baldwin Bridge, Old Saybrook, Conn. (after construction). (From Placzek and others, 1993.)

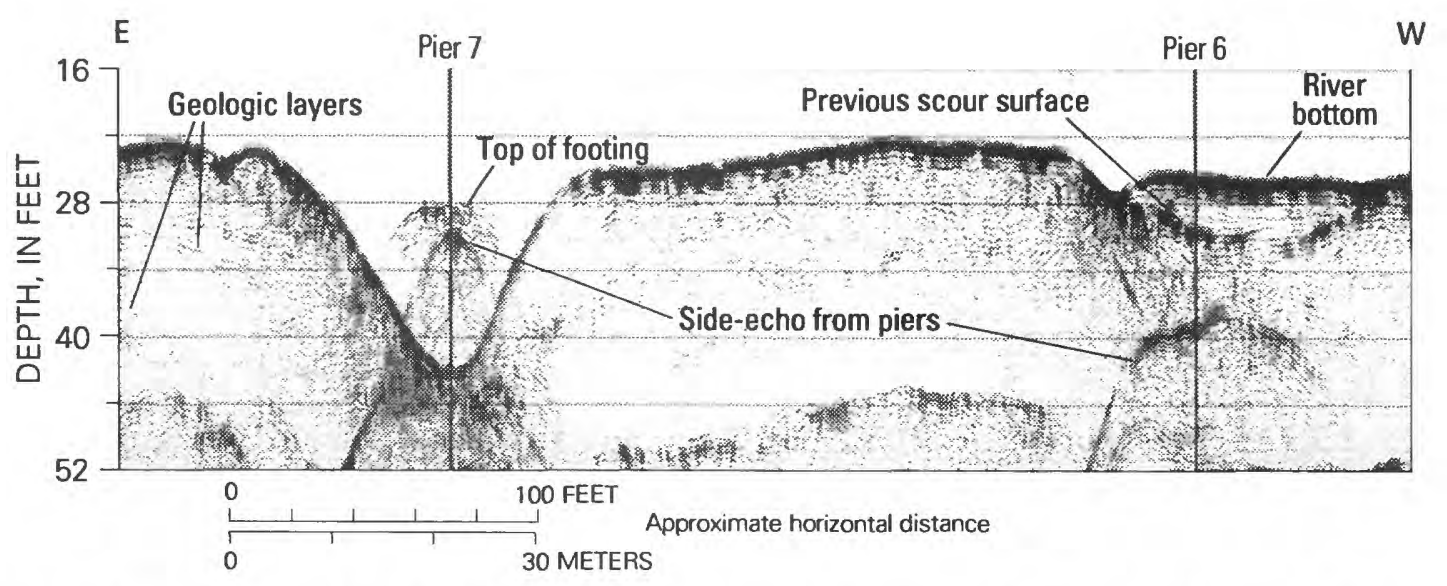

Figure 15. Unpositioned 3.5-kilohertz continuous seismic-reflection profiling data collected 15 feet upstream from the new Baldwin Bridge, Old Saybrook, Conn. (after construction). (From Placzek and others, 1993.) 
At the new Baldwin Bridge site, the CSP data showed the same bathymetric data as the Fathometer records, but in addition, provided information about the subbottom. Fill material up to $5 \mathrm{ft}$ thick in a scour hole was interpreted using the CSP techniques at this site, which was saltwater with a mud bottom and a subbottom consisting of sand and silt. The fixed-frequency and swept-frequency CSP systems produced similar records, although the resolution of the swept-frequency data was higher than the $3.5-$ or $7.0-\mathrm{kHz}$ data.

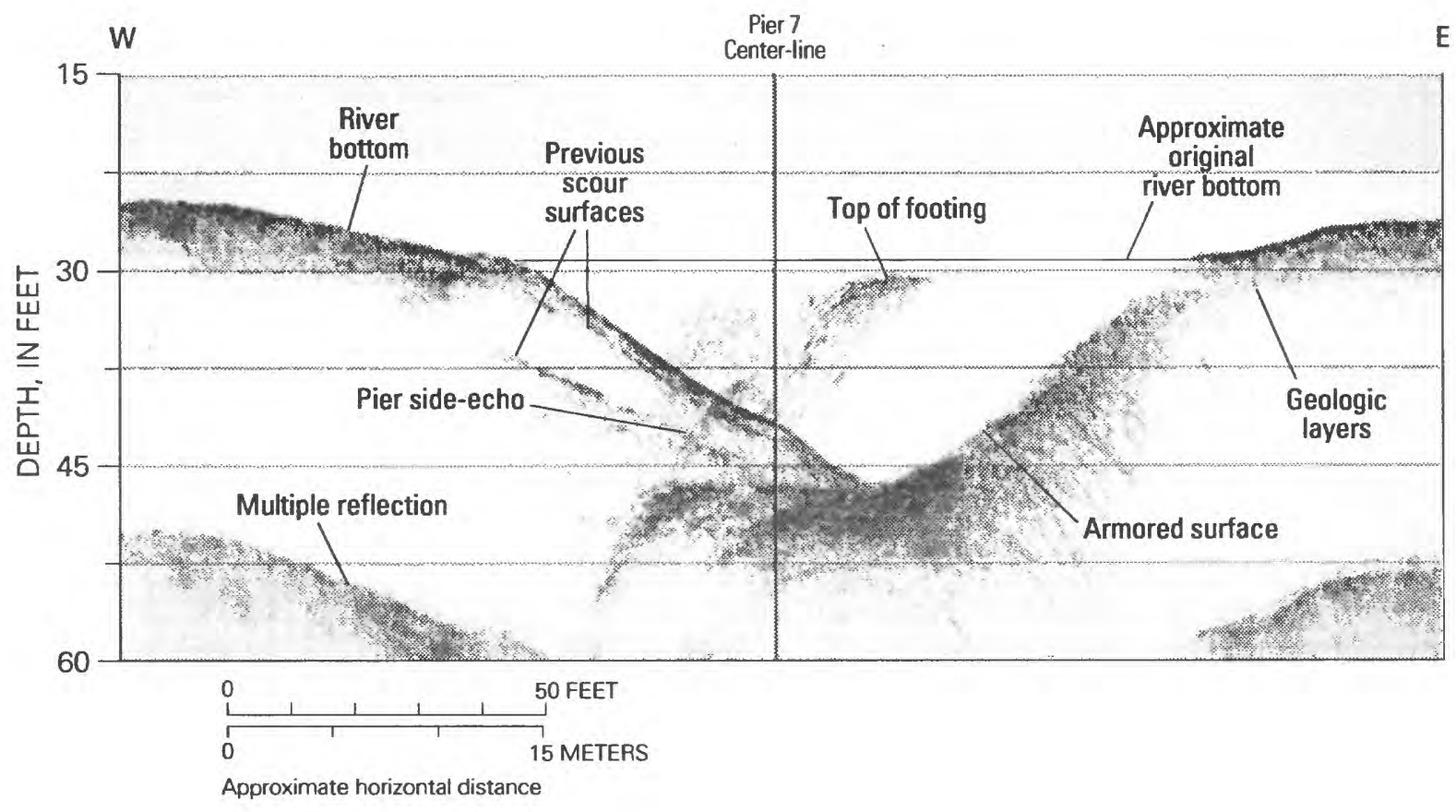

Figure 16. Unpositioned 14-kilohertz continuous seismic-reflection profiling data collected 15 feet upstream from the new Baldwin Bridge, Old Saybrook, Conn. (after construction). 
Route 14 Bridge, Canterbury

The Route 14 bridge spans the $210-\mathrm{ft}$ wide Quinebaug River in Canterbury, Conn. A single pier was located in water that had a maximum depth of $5 \mathrm{ft}$ at the time of the study. The maximum discharge prior to August 1989 at the nearest USGS streamflow-gaging station, located $8 \mathrm{mi}$ downstream near Jewett City, was $42,000 \mathrm{ft}^{3} / \mathrm{s}$ on August 20, 1955 (Cervione and others, 1990). The pier was skewed to the flow creating a potential for scour, but no debris was present around the pier. A lithologic log from the bridgeconstruction plans indicated that the riverbed material consisted of a sand and gravel bottom and a sand and gravel subbottom with some clay; depth to bedrock was more than $45 \mathrm{ft}$. The specific conductance of the water near Jewett City during the 1989 water year ranged from 87 to $150 \mu \mathrm{S} / \mathrm{cm}$ (Cervione and others, 1990).

GPR techniques were used at this site because the water was shallow and the specific conductance was low. CSP techniques were not used at this site because of the shallow water depths. In August 1989, 80- and 300MHz GPR data were collected at this site. The equipment was operated from a 12 -ft fiberglass boat. Multiple cross-sections and lateral sections were collected near the bridge pier. The position of the antenna relative to the pier was visually estimated and noted on the record. The single $80-\mathrm{MHz}$ antenna was difficult to maneuver near the bridge pier and did not provide sufficient resolution, so the $300-\mathrm{MHz}$ antenna was used. Riverbed deposition was detected west of the pier in the $300-\mathrm{MHz}$ GPR data collected $2 \mathrm{ft}$ upstream from the pier (fig. 7). The record shows $2 \mathrm{ft}$ of fill material west of the pier. Hyperbolic images in the record east of the pier indicate a gravel or rip-rap bottom and prevent any shallow subbottom reflectors from being identified. Multiple, smooth, flat-lying, parallel reflectors west of the pier were interpreted as a sand bottom and subbottom; this interpretation was verified by the lithologic log from the bridge-construction plans.

Figure 7 was processed using a migration routine, and the results are shown in figure 8 . The migration routine collapsed the hyperbolas east of the pier to their point sources. The gravel surface is interpreted to be $1 \mathrm{ft}$ below the river bottom, and it may be an old scour or riverbed surface. No subbottom information was obtained below the gravel surface in this record. Processing the data also improved the subbottom interface west of the pier that is interpreted as $4 \mathrm{ft}$ of sand overlying an old channel surface.

The interpreted GPR records at the Route 14 bridge indicate $4 \mathrm{ft}$ of riverbed deposition west of the pier and a gravel surface $\mathrm{l} \mathrm{ft}$ below the river bottom east of the pier. Processing the data allowed the bottom gravel layer to be interpreted.

\section{Bulkeley Bridge, Hartford}

The Bulkeley Bridge carries Interstate 84 over the Connecticut River between East Hartford and Hartford, Conn. A total of eight bridge piers span the $1,060-\mathrm{ft}$ wide river. The piers were numbered from 1 to 8 , starting with the first pier in the water on the west side. Piers 1 and 6 are 170-ft long and 40-ft wide, and the other six piers are $140-\mathrm{ft}$ long and $20-\mathrm{ft}$ wide. The riverbed materials at this site consist of sand overlying glacial lacustrine silt and clay (Haeni and Gorin, 1989). Water depths near the piers ranged from 2 to $30 \mathrm{ft}$ during the study, and the specific conductance of the water from October 1988 to September 1992 ranged from 69 to $155 \mu \mathrm{S} / \mathrm{cm}$ (Cervione and others, 1993). The average water depth $100 \mathrm{ft}$ upstream from the piers was $8 \mathrm{ft}$.

A streamflow-gaging station is located at the Bulkeley Bridge, and the annual mean 
discharge of the Connecticut River between May 1990 and May 1993 was about 17,000 $\mathrm{ft}^{3} / \mathrm{s}$ (Cervione and others, 1993). However, the Connecticut River often floods, and the flow increases to greater than 10 times the average (Ryder and others, 1981). Since 1935, there have been four spring floods during which the river rose more than $30 \mathrm{ft}$ above base level in Hartford (Bell, 1985). The maximum flow was $282,000 \mathrm{ft}^{3} / \mathrm{s}$ on March 20 , 1936 (Cervione and others, 1993).

In June and July 1987, prior to this study, unpositioned $200-\mathrm{kHz}$ black-and-white Fathometer and $20-\mathrm{kHz}$ color Fathometer, 14-kHz CSP, and 80-MHz GPR data were collected at the Bulkeley Bridge (Gorin and Haeni, 1989). Infilled scour holes were detected at piers $3,4,5$, and 6 . In 1988 , three cores were collected from a scour hole upstream from pier 4 to verify the geophysicaldata interpretations.

For this study, positioned $200-\mathrm{kHz}$ black-and-white Fathometer, $20-\mathrm{kHz}$ color Fathometer, 14-kHz CSP, and 100-MHz GPR data were collected and processed in May and October of 1990 (Haeni and Placzek, 1991). In September 1991, unpositioned 1.5- to $10-\mathrm{kHz}$ swept-frequency CSP data were collected, and the following month, a new $14-\mathrm{kHz}$ transducer was used to collect positioned CSP data. In May 1993, positioned 7-kHz CSP data were collected, and new $100-\mathrm{MHz}$ antennas were used to collect positioned GPR data.

A 200-kHz Fathometer was used with the Hydro I positioning system and software to produce horizontally corrected bathymetric profiles of the river bottom in May 1990. A profile of the river bottom, $5 \mathrm{ft}$ upstream from the piers, shows depressions in the river bottom indicating existing scour holes (fig. 2). Multiple lines of Fathometer data were collected upstream, downstream, and alongside pier 4 to determine the size of the scour hole. The hole upstream from pier 4 was about $80 \mathrm{ft}$ wide and $150 \mathrm{ft}$ long. Seven lines of the positioned Fathometer data collected at different distances upstream from the piers were used to create a three-dimensional contour plot of the topography of the river bottom upstream from the piers (fig. 3). The navigation channel and five scour holes at piers 2 through 7 are present. The plot produced a clear three-dimensional image of the size and shape of the scour holes, but the depth of the holes was interpreted more accurately from the $200-\mathrm{kHz}$ Fathometer profiles of the individual cross sections.

Positioned 20-kHz color Fathometer data were collected in May 1990 upstream from the piers, and the data indicated the same bathymetric profile as the $200-\mathrm{kHz}$ Fathometer data. The $20-\mathrm{kHz}$ color Fathometer data also showed fill material in some of the scour holes. At pier $4,5 \mathrm{ft}$ of fill was detected in the scour hole $12 \mathrm{ft}$ upstream from the pier (fig. 17). This record contains a multiple reflection that does not interfere with the area of interest. The positioned $14-\mathrm{kHz}$ CSP data and $100-\mathrm{MHz}$ GPR data, collected in May, also indicate $5 \mathrm{ft}$ of fill material in the scour hole at pier 4. The CSP and GPR data were subsequently processed, which clarified the data interpretation (Haeni and Placzek, 1991).

In September 1991, the Datasonics $1.5-$ to $10-\mathrm{kHz}$ and the 8 - to $23-\mathrm{kHz}$ sweptfrequency CSP systems were used to collect CSP data. The low-frequency system detected scour holes at piers 2 through 7 . More than $4 \mathrm{ft}$ of fill was detected in the holes at piers 3 through 6, and less than $2 \mathrm{ft}$ of fill was detected in the holes at piers 2 and 7 . As much as $6.5 \mathrm{ft}$ of fill was detected at pier 4, and as much as 4 $\mathrm{ft}$ of fill was detected at pier 5 (fig. 18). The high-frequency swept-frequency system did not produce as good a record as the lowfrequency system. The high-frequency system had difficulty locking on the river bottom and had a large amount of system and (or) environmental noise, which degraded the quality of the record. 


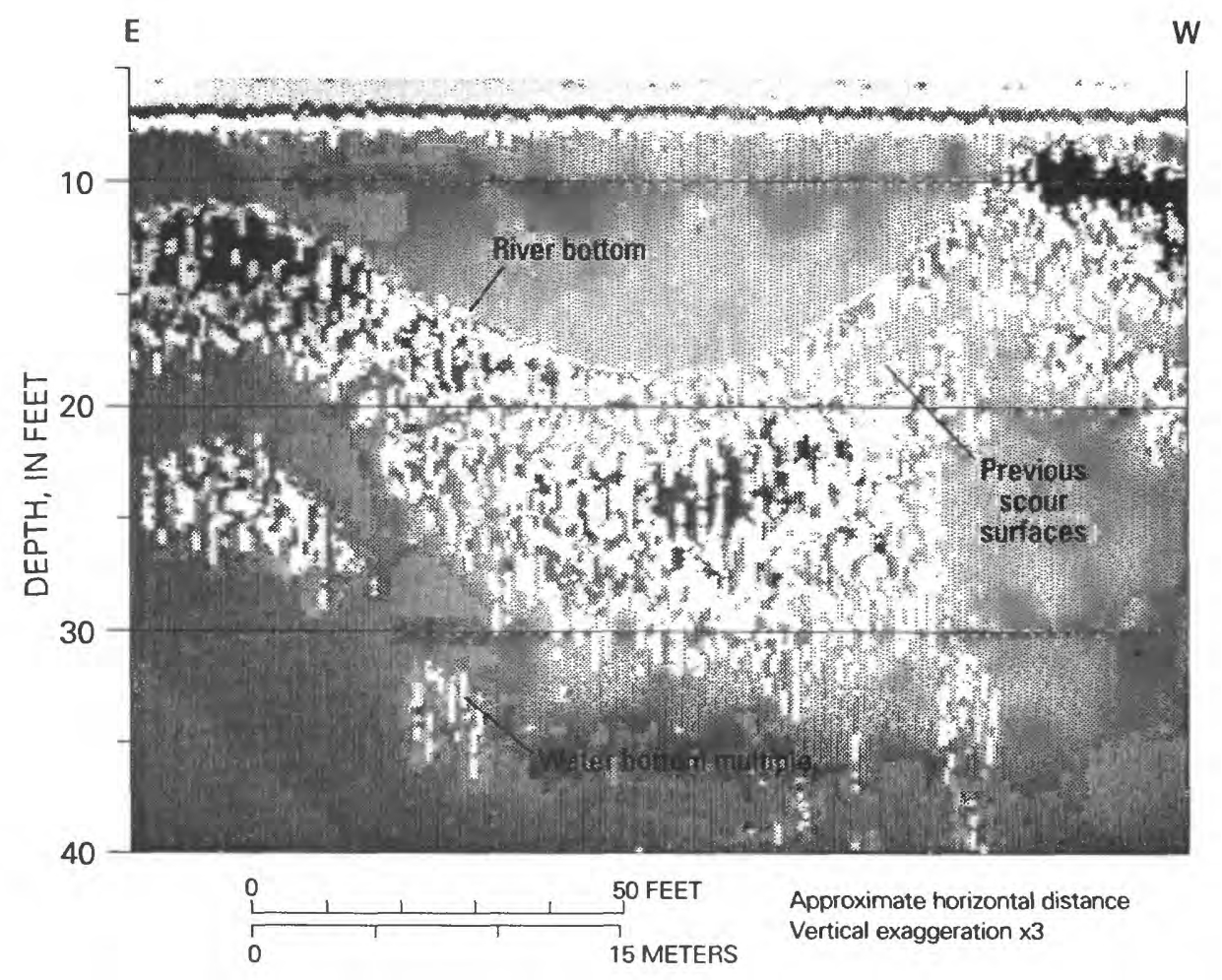

Figure 17. Black-and-white photograph of a 20-kilohertz color Fathometer cross section collected 12 feet upstream from pier 4 of the Bulkeley Bridge, Hartford, Conn. (Modified from Gorin and Haeni, 1989.)

Positioned 14-kHz CSP data collected in October 1991 also indicated six scour holes at six piers of the Bulkeley Bridge. Fill material was detected in five of these holes. Five $\mathrm{ft}$ of fill material was detected in the scour hole $10 \mathrm{ft}$ upstream from pier 4 . The field record (fig. 4) shows an existing 5 - $\mathrm{ft}$ hole with $5 \mathrm{ft}$ of fill material, and the distance between position marks changed, indicating an inconsistent boat speed. The horizontally corrected, filtered, and deconvolved record shows the same scourhole depth and fill material thickness, but also shows steeper sides of the hole and multiple old scour surfaces (fig. 5). The multiple scour surfaces can be explained if the hole had scoured to its maximum depth during the highest recorded flow and then filled gradually over time, or if the hole rescoured and filled during subsequent flood events.
In May 1993, positioned 7-kHz CSP data were collected $20 \mathrm{ft}$ upstream from the piers. The data provided a clearer image of the deep subbottom stratigraphy than the $14-\mathrm{kHz}$ CSP data or the 80 - and $100-\mathrm{MHz}$ GPR data. Existing scour holes were detected $20 \mathrm{ft}$ upstream from piers $3,5,6$, and 7 . Although no existing scour hole was evident, as much as $6 \mathrm{ft}$ of fill in an old scour hole was detected at pier 4 (fig. 19), and as much as $5 \mathrm{ft}$ of fill was detected at piers 5 and 6 . Because of the datacollection mode in which the positioning system was operated, the position marks on the record appear evenly spaced but do not indicate a constant boat speed. The marks signify where position data points were collected and are not necessarily $10-\mathrm{ft}$ increments. 


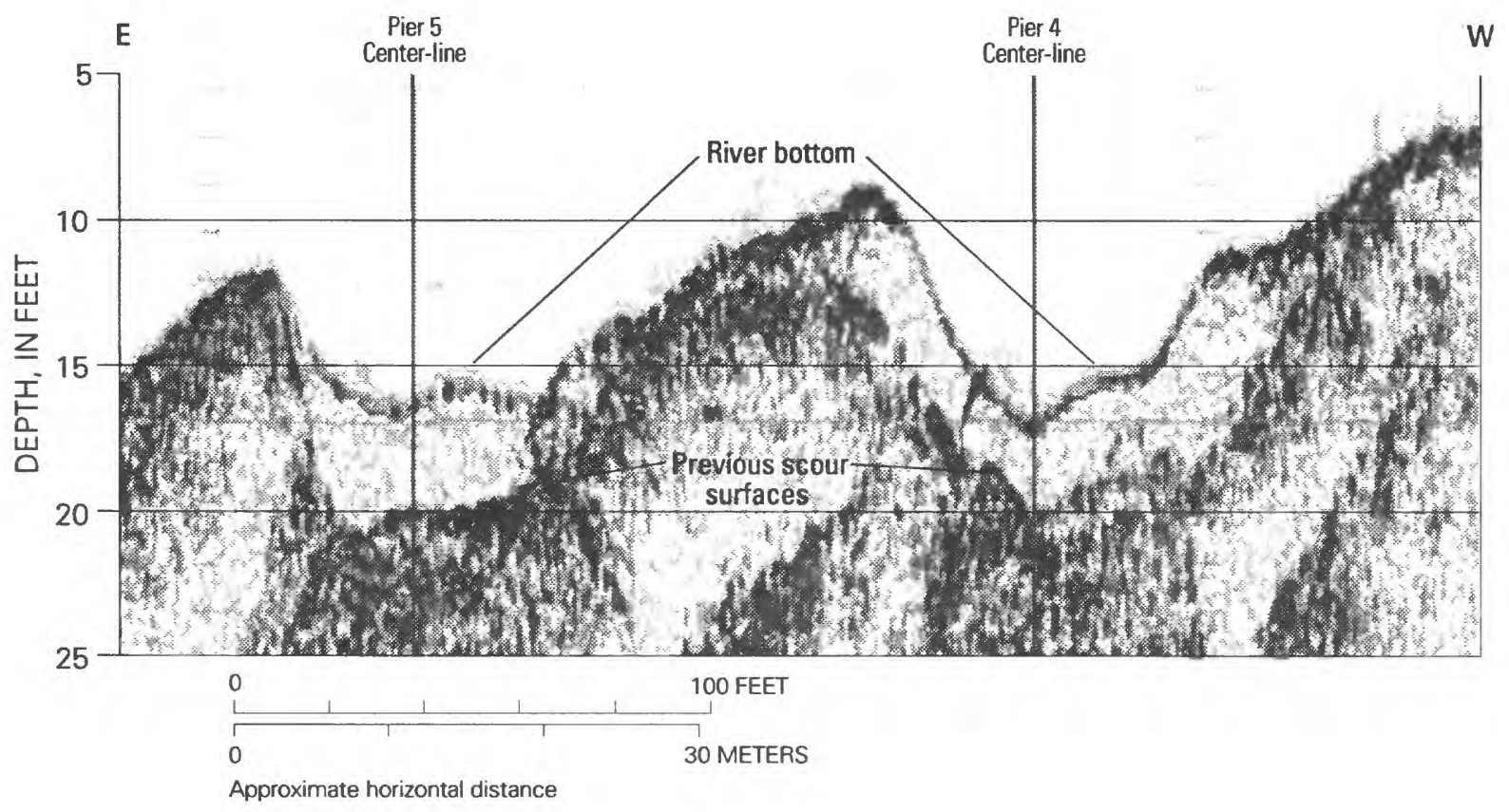

Figure 18. Gray-scale amplitude plot of 1.5- to 10-kilohertz swept-frequency record collected 5 feet upstream from piers 4 and 5 at the Bulkeley Bridge, Hartford, Conn.

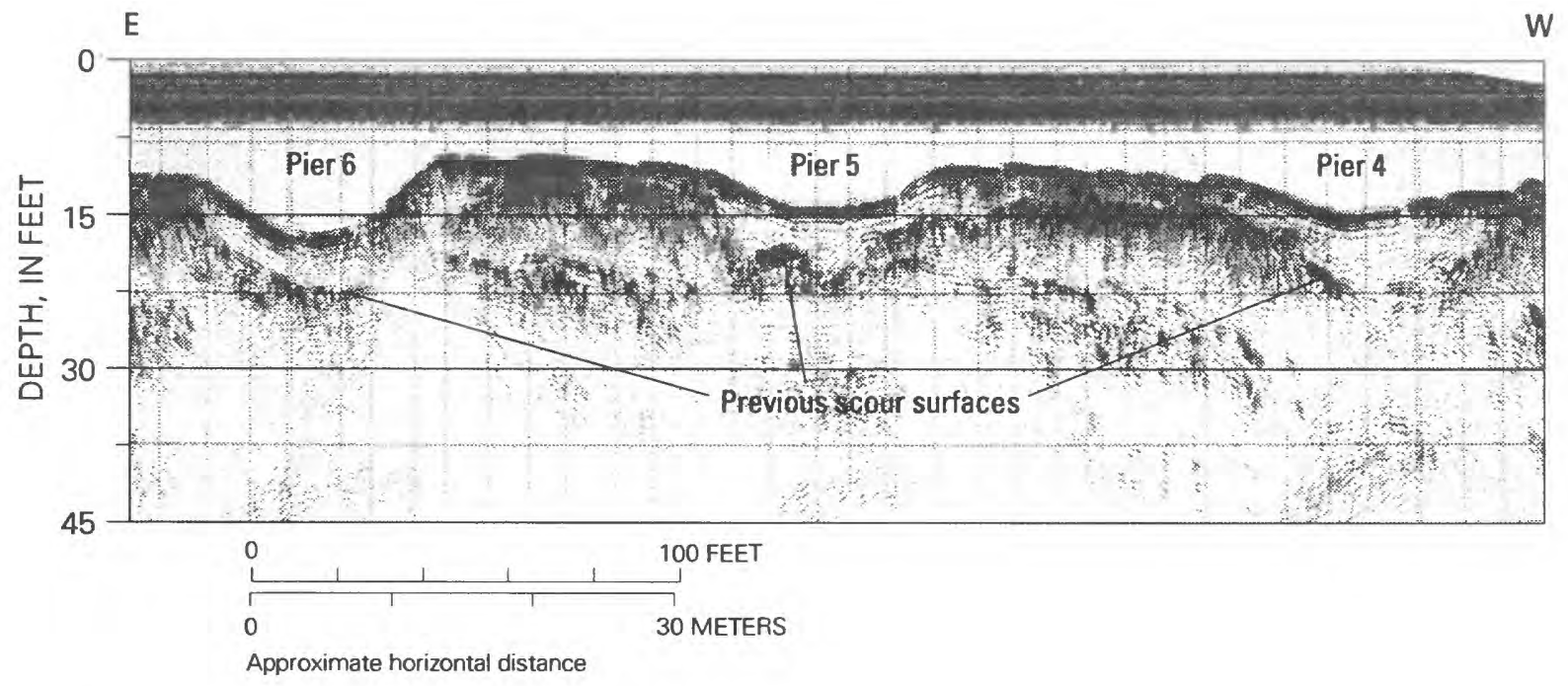

Figure 19. Unpositioned 7-kilohertz continuous seismic-reflection profiling data collected 20 feet upstream from the Bulkeley Bridge, Hartford, Conn. 
Positioned 100-MHz GPR data also were collected in May 1993 using the modified antennas built for this study. Infilled scour holes were detected near piers 2 to 7 . The data showed $5 \mathrm{ft}$ of fill material at the bottom of a 10 -ft deep hole $15 \mathrm{ft}$ upstream from pier 5 and $3 \mathrm{ft}$ of fill material on the east side of a 13-ft deep hole $15 \mathrm{ft}$ upstream from pier 4 (fig. 20). A 9-ft deep scour hole detected at pier 2 in 1987 (pier 7 in Gorin and Haeni, 1989, p. 11) had filled in and was only $4 \mathrm{ft}$ deep in 1993. The GPR data did detect the old scour surface from 1987, $5 \mathrm{ft}$ below the 1993 river bottom.

The 20-kHz color Fathometer, 7- and 14-kHz CSP system, $1.5-10 \mathrm{kHz}$ sweptfrequency CSP system, and the $100-\mathrm{MHz}$ GPR system provided subbottom information used to interpret the thickness of fill material in scour holes at this site. The geophysical data collected with all of the techniques indicated that about $5 \mathrm{ft}$ of material filled the hole at pier 4. The seismic data provided subbottom information to $25 \mathrm{ft}$ (to bedrock) and the radar data provided subbottom information to $10 \mathrm{ft}$ (to the glacial lacustrine clay). The water depth, specific conductance, and physical setting allowed the color Fathometer, CSP, and GPR techniques to detect scour surfaces in the subbottom of the river at this site.

The three core samples previously collected at pier 4 correlated with all the geophysical data collected at this site. The grain-size distribution of the fill material in the scour hole ranged from fine sand near the water bottom to very coarse sand, with a few large pebbles at the bottom of the fill material. Glacial lacustrine silt and clay underlie the fill material. Detailed results of the coring are described in Haeni and Gorin (1989).

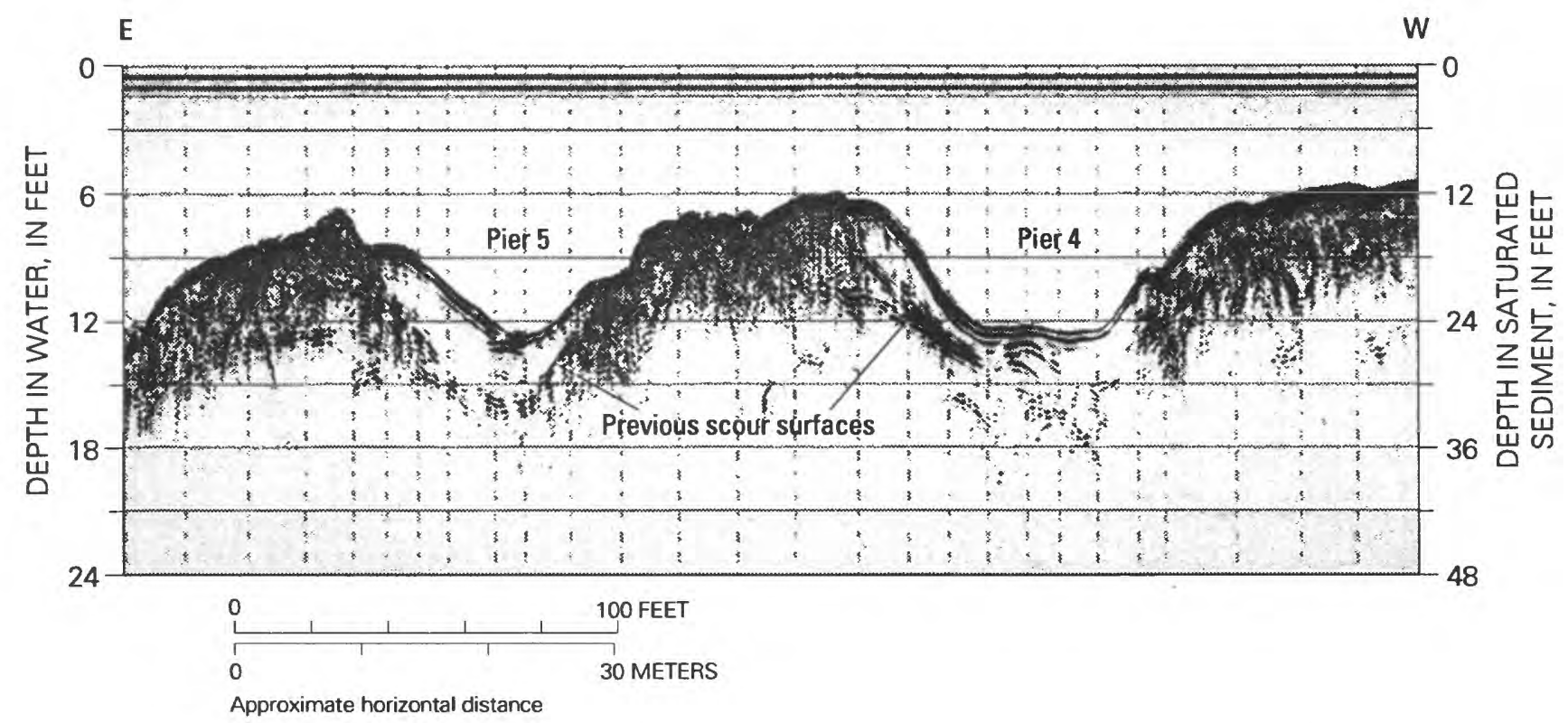

Figure 20. Positioned 100-megahertz ground-penetrating radar data collected 15 feet upstream from piers 4 and 5 of the Bulkeley Bridge, Hartford, Conn. 


\section{Route 4 Bridge, Farmington}

The Route 4 bridge spans the $310-\mathrm{ft}$ wide Farmington River in Farmington, Conn. Three piers were located in water that was less than $10 \mathrm{ft}$ deep during this study. The nearest USGS streamflow-gaging station is $3.5 \mathrm{mi}$ upstream near Unionville, and the maximum discharge recorded prior to October 1991 was $140,000 \mathrm{ft}^{3} / \mathrm{s}$ on August 19, 1955 (Cervione and others, 1993). Rip-rap was present on both river banks, and no debris was present around the piers at the time of the study. A lithologic log from the bridge plans indicated that the riverbed material consists of a sand bottom and subbottom. The specific conductance of the water near Unionville from August 1990 to October 1991 ranged from 64 to $100 \mu \mathrm{S} / \mathrm{cm}$ (Cervione and others, 1993).

In August 1990, 100-MHz GPR data and $200-\mathrm{kHz}$ Fathometer data were collected simultaneously by a two-person crew in a $13-\mathrm{ft}$ inflatable boat powered by a 6-horsepower engine. The 100-MHz GPR data showed no fill material in a 3-ft scour hole on the upstream side of the center pier. In October 1991, 300$\mathrm{MHz}$ GPR data were collected. A 3-ft deep scour hole was detected $4 \mathrm{ft}$ to the left of the upstream side of the center pier, and a mound of material was detected at the downstream side (fig. 21). No fill material in the scour hole was detected.

GPR records were collected successfully at this site, but no deep scour holes were detected. One interpretation of this is that little scour has occurred at this site. The detection of a coarse sand or gravel layer beneath a finer sand layer elsewhere in the records indicates that the GPR technique did work in this physical setting.

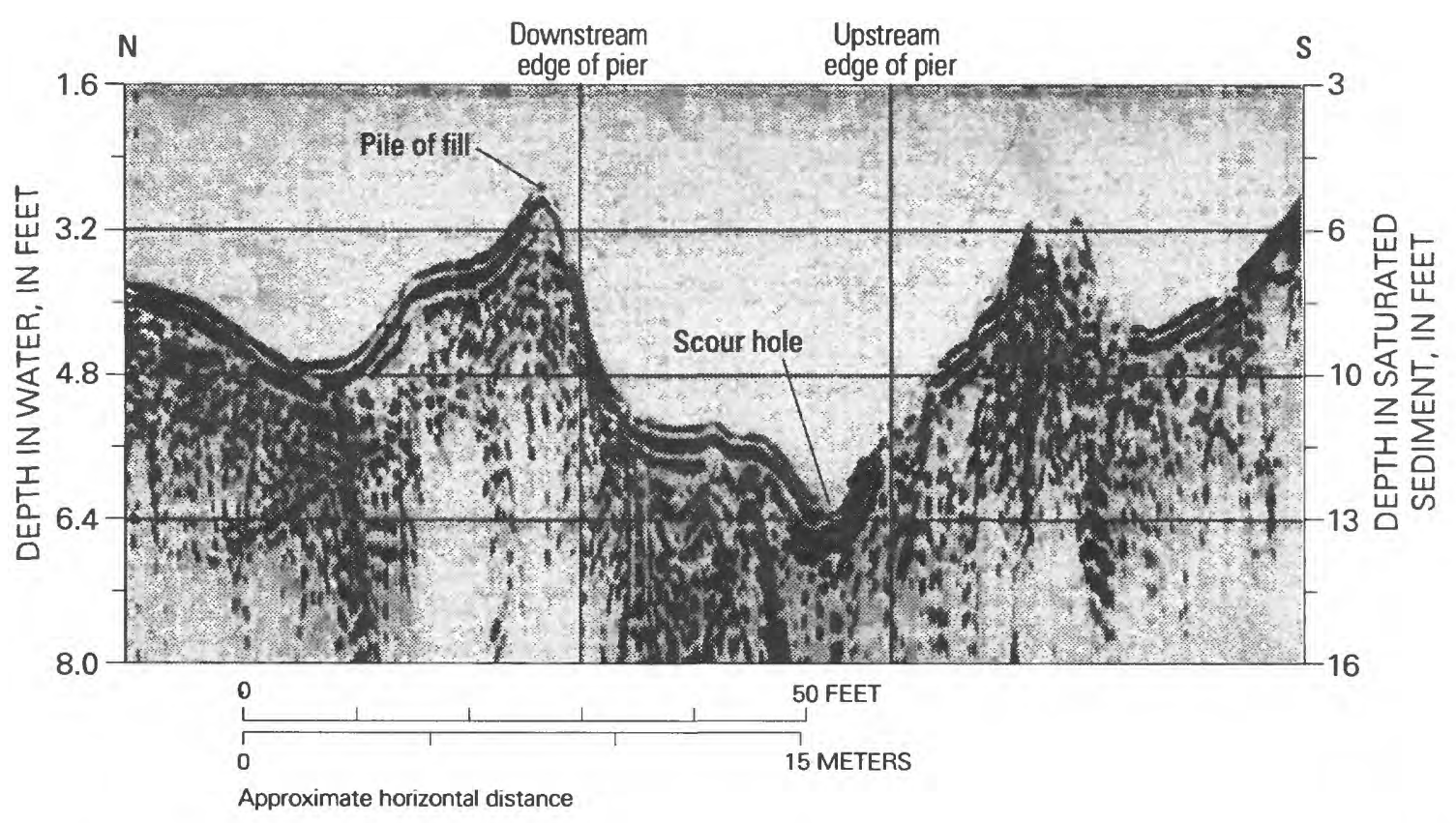

Figure 21. Unpositioned 300-megahertz ground-penetrating radar data collected 4 feet east of the center pier at the Route 4 Bridge, Farmington, Conn. 


\section{Route 2 Bridge, Norwich}

The Route 2 bridge spans the $200-\mathrm{ft}$ wide Shetucket River in Norwich, Conn., and two round-nose piers are located in water that has a maximum depth of $15 \mathrm{ft}$. A maximum discharge at this site of $68,000 \mathrm{ft}^{3} / \mathrm{s}$ on August 20,1955 was calculated using data collected 7 mi upstream on the Quinebaug River near Jewett City and $16 \mathrm{mi}$ upstream on the Shetucket River near Willimantic (Cervione and others, 1990). The riverbed materials consist of a sand and gravel bottom and a sand subbottom (Cervione and others, 1968, p. 44). The river was wide and deep enough to use a 22 -ft boat for data collection. The location of the transducers was estimated and noted on the records. GPR techniques were not used at this site because saltwater was present.

In June 1991, 14-kHz CSP data were collected from a 13-ft boat and in October 1991, 20- and 200-kHz Fathometer and 7-kHz CSP data were collected from a $22-\mathrm{ft}$ boat. The
Fathometer data (fig. 22) detected that the top of the footing $3 \mathrm{ft}$ upstream from pier 1 was exposed at a depth of $13 \mathrm{ft}$ and the river bottom was at $17 \mathrm{ft}$, indicating that a 4 -ft scour hole was present. No evidence of scour was detected near pier 2. No side echoes from piers were present on the Fathometer record, but the 7 - and $14-\mathrm{kHz}$ CSP data did contain side echoes. The CSP data contained the same bathymetric data as the Fathometer data and did not indicate the presence of any infilled scour holes. The $20-\mathrm{kHz}$ color Fathometer data confirmed the presence and depth of the footing and the existing scour hole, but provided no subbottom information.

The CSP and 20-kHz Fathometer records did not detect an old scour surface at pier 1 or 2, indicating either that no infilled scour holes were present, or that the fill material was less than $1 \mathrm{ft}$ thick, the maximum resolution of the techniques. Probing near the hole confirmed that the footing was exposed and that there was no fill material in the hole.

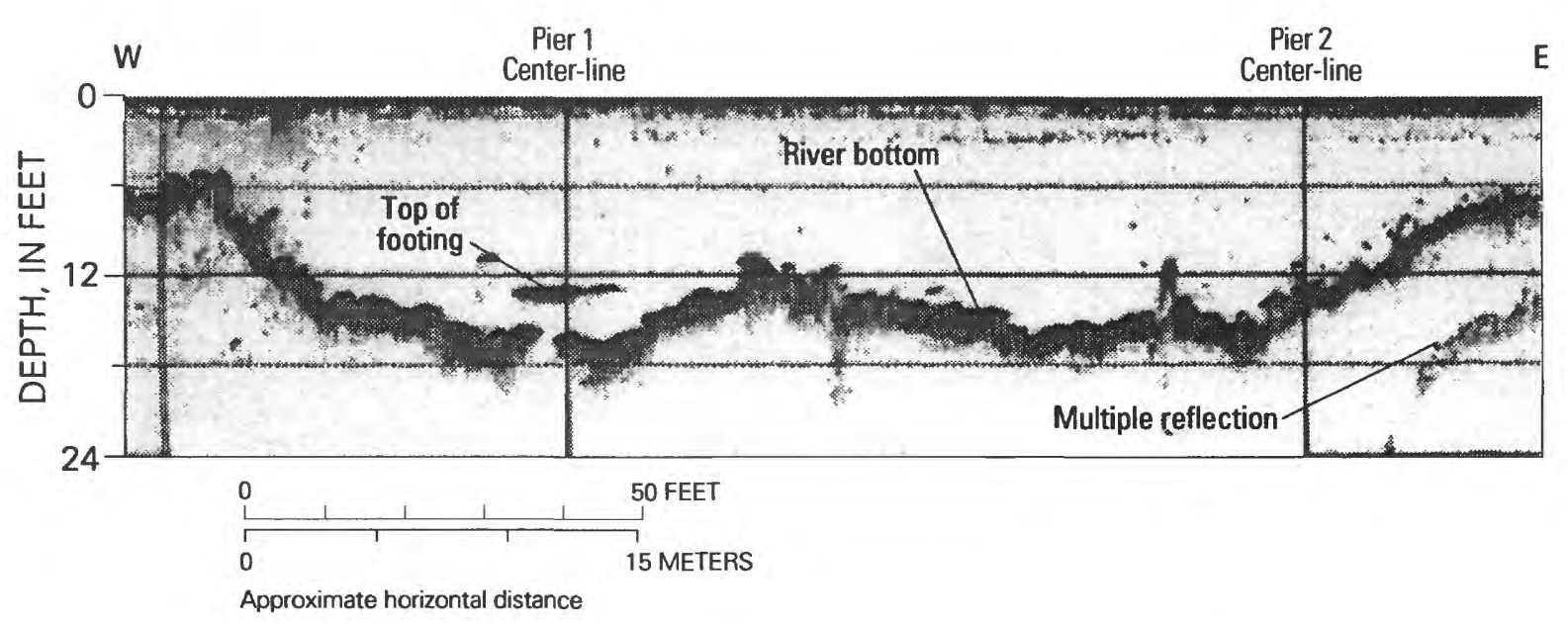

Figure 22. Unpositioned 200-kilohertz Fathometer data collected 3 feet upstream from the piers at the Route 2 Bridge, Norwich, Conn. 


\section{FUTURE EQUIPMENT MODIFICATIONS AND RESEARCH NEEDS}

During this study, modifications were made to equipment, and field procedures and interpretation methods were developed for studying scour near bridge piers. Future equipment modifications and other areas of research include:

(1) The $14-\mathrm{kHz}$ dual-element transducer has not been fully tested with the active ring-damping circuit at bridge-scour sites. This system has the potential to be used in very shallow $(3 \mathrm{ft})$ water. Further applications of this transducer and an evaluation of its performance are needed.

(2) The GPR system can record field data onto DAT cartridges using the GSSI model 38 interface. By implementing this interface, GPR data can be stored on a material common to all systems, making future datatransfer procedures simpler than present ones.

(3) Geophysical data recorded on a DAT cartridge can be transferred directly to a PC by a strictly digital link, rather than through a digital-to-analog and analog-todigital card. The digital link would provide an easier transfer procedure with less noise and less hardware dependence on unique systems. The digital link required is commercially available, although some software may need to be developed.

(4) A processing procedure could be developed to correct for vertical-scale changes in GPR data when the signal passes through materials with different velocities. A single, corrected vertical scale would provide a geophysical record that more closely resembles the actual geometry of the site.

(5) Development and documentation of multiple suppression, side-echo reduction, and adaptive filtering techniques may help reduce the noise and interference in geophysical data collected near bridge piers.

(6) A variable time-varying gain may account for the varying amplitude of the incident wave in different water depths and can relate the amplitude of the reflected signal to the reflection coefficient, which can be related to material types.

(7) New geophysical instruments that could be used to detect and measure riverbed scour are constantly being developed. Some commercially available systems that may apply to scour studies include:

(a) Swept-frequency systems that use a smaller transducer and a broader bandwidth signal (4 to $20 \mathrm{kHz}$ ), and are less expensive than the systems used in this study.

(b) Dual-frequency color Fathometers that allow a dual-display of high- and lowfrequency data.

(c) Low-frequency Fathometer systems, such as the 128-kHz InnerSpace 4516 , may provide limited penetration depths and high resolution required in a scour study.

(d) Stationary scanning multi-beam bathymetric sonar devices, such as the Scour Fish developed by American Inland Divers, Inc. or Sea Bat developed by Reson, Inc.,which provide bathymetric data that can be used to evaluate scour conditions.

(e) High-resolution multiplefrequency subbottom profilers that are used by Rijkswaterstaat in Holland to obtain subbottom information for dredging. The System 80 , manufactured by Ulvertech Limited in England, has a small transducer with a beam width less than $5^{\circ}$ over the 5 - to $20-\mathrm{kHz}$ frequency range. The system generates this narrow beam, low-frequency signal from two offset high-frequency transmissions. 


\section{SUMMARY AND CONCLUSIONS}

Fathometer, CSP, and GPR techniques were used to detect and measure the depth and extent of existing and infilled scour holes near bridge piers. Methods were developed to apply these surface-geophysical techniques near bridge piers and to process and interpret the data. The geophysical techniques used at a given site were chosen on the basis of penetration depth and resolution requirements, as well as physical site characteristics, such as water depth and specific conductance. Performance criteria of the surface-geophysical techniques used in this study are summarized in table 3 . This includes idealized and achieved values of resolution capability and penetration depth. Achieved values may differ from idealized values because the techniques were not applied under ideal conditions or the geologic conditions were not present to adequately test the technique.

Most of the geophysical equipment was standard and commercially available, but some modifications were required. The $80-$ and $100-\mathrm{MHz}$ GPR antennas were waterproofed, and a new case was designed and constructed for the $100-\mathrm{MHz}$ antenna. An active ring-damping circuit and a dual-element
14-kHz transducer improved the quality of the CSP data. All geophysical instruments were mounted in shipping cases that increased portability and field durability of the equipment.

Geophysical data were collected at six bridge sites in Connecticut. Scour holes-both with and without fill material in them-were detected. In addition, riverbed deposition from a migrated river channel, depth to geologic layers, buried rip-rap, and exposed pier footings were detected. A summary of the sites, their characteristics, and the results of the techniques used at the sites is shown in table 4.

After data collection, the geophysical data were interpreted, and all available data from the site were correlated. A process developed to transfer data from tape cartridges to the PC allowed Fathometer, CSP, and GPR data to be processed using commercially available software. The processing of the data resulted in more accurate interpretations and improved data displays. Bathymetric profiles, position data, and verification data supplemented the geophysical data to confirm the depth and extent of scour holes, thickness of fill material in the holes, location of exposed footings, location of previous channels, and depth to other geologic layers.

\section{Table 3. Summary of performance criteria for selected surface-geophysical techniques}

$[\mathrm{kHz}$, kilohertz; $\mathrm{MHz}$, megahertz; idealized value is the manufacturer claim or theoretical maximum; achieved value is that obtained during this study; --, no manufacturer claim]

\begin{tabular}{|c|c|c|c|c|c|c|}
\hline \multirow[b]{2}{*}{$\begin{array}{l}\text { Geophysical } \\
\text { technique }\end{array}$} & \multirow[b]{2}{*}{ Material type } & \multirow[b]{2}{*}{$\begin{array}{c}\text { Signal } \\
\text { frequency }\end{array}$} & \multicolumn{2}{|c|}{$\begin{array}{l}\text { Resolution capability } \\
\text { (feet) }\end{array}$} & \multicolumn{2}{|c|}{$\begin{array}{l}\text { Penetration depth } \\
\text { (feet) }\end{array}$} \\
\hline & & & Idealized & Achieved & Idealized & Achieved \\
\hline \multirow[t]{2}{*}{ Fathometers } & \multirow{2}{*}{$\begin{array}{l}\text { Fine-grained } \\
\text { (silts and clays) }\end{array}$} & $200 \mathrm{kHz}$ & 0.3 & 0.5 & - & 0 \\
\hline & & $20 \mathrm{kHz}$ & 0.5 & 1 & - & 10 \\
\hline \multirow{4}{*}{$\begin{array}{l}\text { Continuous } \\
\text { seismic-reflection } \\
\text { profilers }\end{array}$} & \multirow{4}{*}{$\begin{array}{l}\text { Fine-grained } \\
\text { (silts and clays) }\end{array}$} & $14 \mathrm{kHz}$ & 1 & 1 & 20 & 20 \\
\hline & & $7 \mathrm{kHz}$ & 2 & 2 & 40 & 25 \\
\hline & & $3.5 \mathrm{kHz}$ & 2.5 & 2.5 & 100 & 50 \\
\hline & & 2 to $16 \mathrm{kHz}$ & 0.3 & 1 & 200 & 50 \\
\hline \multirow{3}{*}{$\begin{array}{l}\text { Ground-penetrating } \\
\text { radar system }\end{array}$} & \multirow{3}{*}{$\begin{array}{l}\text { Electrically } \\
\text { resistive and } \\
\text { granular }\end{array}$} & $300 \mathrm{MHz}$ & 1 & 1 & 40 & 10 \\
\hline & & $100 \mathrm{MHz}$ & 2 & 2 & 40 & 40 \\
\hline & & $80 \mathrm{MHz}$ & 2.5 & 2.5 & 100 & 50 \\
\hline
\end{tabular}




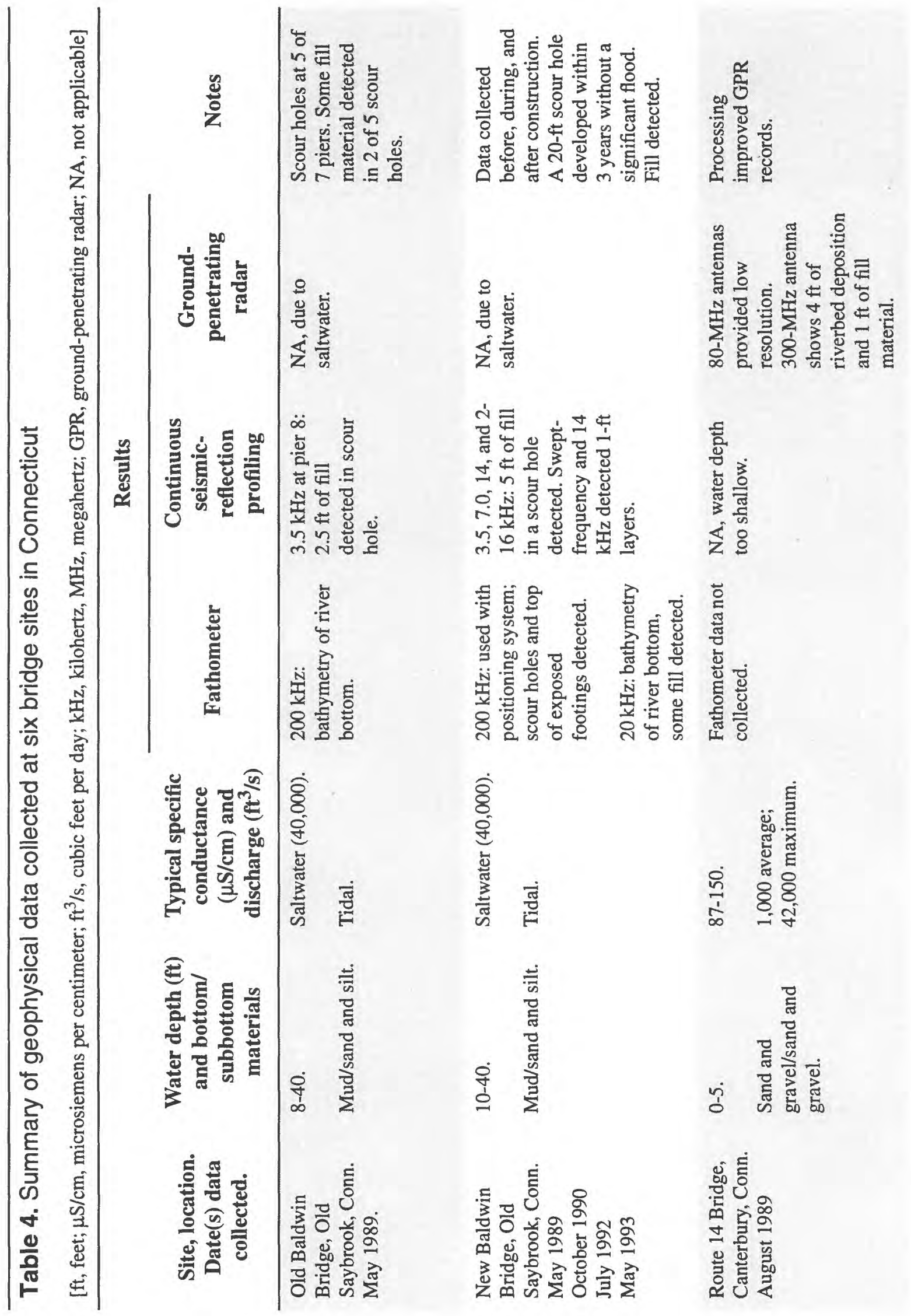




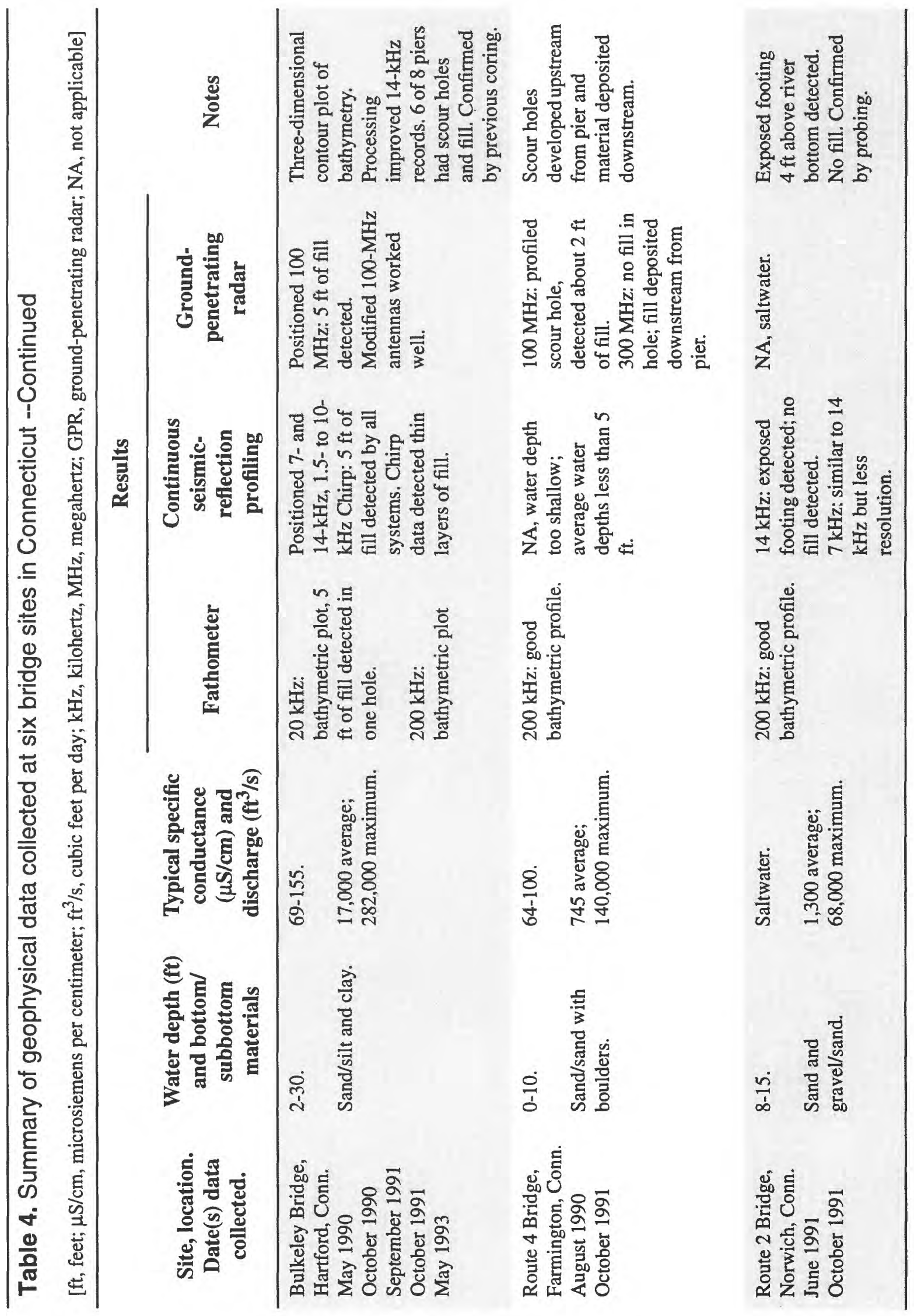




\section{REFERENCES CITED}

Anderson, A.G., 1974, Scour at bridge waterways - a review: Washington, D.C., U.S. Federal Highway Administration, RD-75-89, 29 p.

Bell, Michael, 1985, The face of Connecticut: State Geological and Natural History Survey of Connecticut Bulletin 110, p. 2631.

Beres, Milan, and Haeni, F.P., 1991, Application of ground-penetrating-radar methods in hydrogeologic studies: Ground Water, v. 29, no. 3, p. 375-386.

Bingham, J.W., Paine, F.D., and Weiss, L.A., 1975, Hydrogeologic data for the lower Connecticut River basin, Connecticut: Connecticut Water Resources Bulletin 30, $59 \mathrm{p}$.

Cardinell, A.P., Harned, D.A., and Berg, S.A., 1990, Continuous seismic reflection profiling of hydrogeologic features beneath New River, Camp Lejeune, North Carolina: U.S. Geological Survey WaterResources Investigations Report 89-4195, $33 \mathrm{p}$.

Cervione, M.A., Jr., Davies, B.S. 3rd, Bohr, J.R., and Hunter, B.W., 1990, Water resources data, Connecticut, water year 1989: U.S. Geological Survey Water-Data Report CT-89-1, 321 p.

---- 1991, Water resources data, Connecticut, water year 1990: U.S. Geological Survey Water-Data Report CT-90-1, 265 p. 1992, Water resources data, Connecticut, water year 1991: U.S. Geological Survey Water-Data Report CT-91-1, 255 p. 1993, Water resources data, Connecticut, water year 1992, U.S. Geological Survey Water-Data Report CT-92-1, 261 p.

Cervione, M.A., Jr., Grossman, I.G., and Thomas, C.E., Jr., 1968, Hydrogeologic data for the lower Thames and southeastern coastal river basins, Connecticut: Connecticut Water Resources Bulletin 16, 65 p.
Crumrine, M.D., 1991, Results of a reconnaissance bridge-scour study at selected sites in Oregon using surfacegeophysical methods: U.S. Geological Survey Water-Resources Investigations Report 90-4199, 44 p.

Faas, R.W., 1969, Analysis of the relationship between acoustic reflectivity and sediment porosity: Geophysics, v. 34, no. 4, p. 546-553.

Geophysical Survey Systems, Inc., 1987, Operation Manual, Subsurface Interface Radar SIR System 8: Hudson, New Hampshire, Geophysical Survey Systems, Inc., p. 18-20.

Gorin, S.R., and Haeni, F.P., 1989, Use of surface-geophysical methods to assess riverbed scour at bridge piers: U.S. Geological Survey Water- Resources Investigations Report 88-4212, 33 p.

Haeni, F.P., 1986, Application of continuous seismic reflections methods to hydrologic studies: Ground Water, v. 24, no. 1, p. 2331.

Haeni, F.P., 1988, Application of seismicrefraction techniques to hydrologic studies: U.S. Geological Survey Techniques of Water-Resources Investigations, book 2, chap. D2, $86 \mathrm{p}$. 1992, Use of ground-penetrating radar and continuous seismic-reflection profiling on surface-water bodies in environmental and engineering studies, in Bell, R.S. (ed.), Symposium on the Application of Geophysics to Engineering and Environmental Problems, Oakbrook, Illinois, April 26-29, 1992, Proceedings: Golden, Colorado, Society of Engineering and Mineral Exploration Geophysicists, p. 145-162.

Haeni, F.P., and Gorin, S.R., 1989, Post-flood measurement of an infilled scour hole at the Bulkeley Bridge in Hartford, Connecticut, in Proceedings of the Bridge Scour Symposium: McLean, Virginia, Federal Highway Administration Report FHWA-RD-90-035, p. 147-174. 
Haeni, F.P., McKeegan, D.K., and Capron, D.R., 1987, Ground penetrating radar study of the thickness and extent of sediments beneath Silver Lake, Berlin and Meriden, Connecticut: U.S. Geological Survey Water- Resources Investigations Report 85-4108, 19 p.

Haeni, F.P., and Placzek, Gary, 1991, Use of processed geophysical data to improve the delineation of infilled scour holes at bridge piers, in Expanded Abstracts with Biographies, SEG 61st Annual International Meeting, Houston, Texas, November 10-14, 1991: Houston, Texas, Society of Exploration Geophysicists, p. 549-552.

Haeni, F.P., Placzek, Gary, and Trent, R.E., 1992, Use of ground-penetrating radar to investigate infilled scour holes at bridge foundations, in Hanninen, Pauli and Autio, Sini (eds.), Fourth International Conference on Ground Penetrating Radar, Rovaniemi, Finland, June 8-13, 1992 , Proceedings: Geological Survey of Finland Special Paper 16, p. 285-292.

Hamilton, E.L, 1970, Reflection coefficients and bottom losses at normal incidence computed from Pacific sediment properties: Geophysics, v. 35, no. 6, p. 995-1004.

Hansen, B.P., 1986, Use of continuous seismic-reflection methods in a hydrologic study in Massachusetts, a case study, in National Water Well Association Conference on Surface and Borehole Geophysical Methods and Ground Water Instrumentation, Denver, Colorado, October 15-17, 1986, Proceedings: Worthington, Ohio, National Water Well Association, p. 381-395.

Hart, E.D., and Caulfield, D.D., 1989, Acoustic determination of bridge scour, in Proceedings of the Bridge Scour Symposium: McLean, Virginia, Federal Highway Administration Report FHWARD-90-035, p. 130-146.
Hopkins, G.R., Vance, R.W., and Kasraie, B., 1980, Scour around bridge piers: Washington, D.C., U.S. Federal Highway Administration RD-79-103, 131 p.

Horne, G.S., and Patton, P.C., 1989, Bed loadsediment transport through the Connecticut River estuary: Geological Society of America Bulletin, v. 101, p. 805-819.

Jarrett, R.D., and Boyle, J.M., 1986, Pilot study for collection of bridge scour data: U.S. Geological Survey Water-Resources Investigations Report 86-4030,46 p.

Morrissey, D.J., Haeni, F.P., and Tepper, D.H., 1985, Continuous seismic-reflection profiling of glacial-drift deposits on the Saco River, Maine and New Hampshire: National Water Well Association Annual Eastern Regional Groundwater Conference, 2nd, Portland, Maine, 1985 , Proceedings, p. 277- 296.

Mueller, D.S., Miller, R.L., and Wilson, J.T., 1994, Historical and potential scour around bridge piers and abutments of selected stream crossings in Indiana: U.S. Geological Survey Water-Resources Investigations 93-4066, 109 p.

Murillo, J.A., 1987, The scourge of scour: Civil Engineering, July 1987, p. 66-69.

Olhoeft, G.R., 1984, Applications and limitations of ground-penetrating radar [abs], in Society of Exploration Geophysicists 54th Annual International Meeting, Atlanta, Georgia: Houston, Texas, Society of Exploration Geophysicists, p. 147-148.

Parrott, D.R., Dodds, D.J., King, L.H., and Simpkin, P.G., 1980, Measurement and evaluation of the acoustic reflectivity of the sea floor: Canadian Journal of Earth Science, v. 17, p. 722-737.

Placzek, Gary, Haeni, F.P., and Trent, R.E., 1993, Use of geophysical data to assess scour development, in Hydraulic Engineering '93, National Conference on Engineering Hydrology, San Francisco, 
July 25-30, 1993, Proceedings: American Society of Civil Engineers, p. 2051-2056. Reynolds, R.J., and Williams, J.H., 1988, Continuous seismic-reflection profiling of glacial drift along the Susquehanna, Chemung, and Chenango Rivers, southcentral New York and north-central Pennsylvania, in Randall, A.D., and Johnson, A.I. (eds.), Regional aquifer systems of the United States-the northeast glacial aquifers: American Water Resources Association Monograph 11, p. 83-103.

Richardson E.V., Harrison, L.J., and Davis, S.R., 1991,Evaluating scour at bridges: Washington, D.C., Federal Highway Administration FHWA-IP-90-017, Hydraulic Engineering Circular 18, 191 p. Richardson, E.V., and Richardson, J.R., 1989, Bridge scour in Proceedings of the Bridge Scour Symposium: McLean, Virginia, Federal Highway Administration Report FHWA-RD-90-035, p. 1-42.

Ryder, R.B., Thomas, M.P., and Weiss, L.A., 1981, Water resources inventory of Connecticut, part 7, upper Connecticut River basin: Connecticut Water Resources Bulletin 24, 78 p.

Schock, S.G., and LeBlanc, L.R., 1990, Chirp sonar-new technology for sub-bottom profiling: Sea Technology, October 1990, p. 35-43.

Sheriff, R.E., 1984, Encyclopedic dictionary of exploration geophysics: Tulsa, Oklahoma, Society of Exploration Geophysics, p. 270.

Sylwester, R.E., 1983, Single-channel, highresolution seismic-reflection profiling, a review of the fundamentals and instrumentation: in Geyer, R.A. (ed.), Handbook of Geophysical Exploration at Sea: Boca Raton, Florida, CRC Press, p. 77-122.

Thompson, T.A., Miller, C.S., Doss, P.K., Thompson, L.D.P., and Baedke, S.J., 1991, Land-based vibracoring and vibracore analysis-tips, tricks, and traps: Bloomington, Indiana, Indiana Department of Natural Resources Occasional Paper 58, 13 p.

Trent, R.E., and Friedland, Ian, 1992, Status of scour instrumentation development, in Proceedings of the American Society of Chemical Engineers Water Forum, Baltimore, Maryland, August 1992: American Society of Civil Engineers, 6 p. Trent, R.E., and Landers, M.N., 1991, Chasing floods and measuring scour, in Third Bridge Engineering Conference, Transportation Research Board: Washington, D.C., National Research Council, TRB 1290.

Wright, D.L., Olhoeft, G.R., and Watts, R.D., 1984, Ground penetrating radar studies on Cape Cod, in Nielsen, D.M., and Curl, Mary (eds.), National Water Well Association/U.S. Environmental Protection Agency Conference on Surface and Borehole Geophysical Methods in Ground-Water Investigations, San Antonio, Texas, Proceedings: Worthington, Ohio, National Water Well Association, p. 666-680. 